\title{
Quantification of regional leachate variance from municipal solid waste landfills in
} China

Yang, Na; Damgaard, Anders; Kjeldsen, Peter; Shao, Li-Ming; He, Pin-Jing

Published in:

Waste Management

Link to article, DOI:

10.1016/j.wasman.2015.09.016

Publication date:

2015

Document Version

Peer reviewed version

Link back to DTU Orbit

Citation (APA):

Yang, N., Damgaard, A., Kjeldsen, P., Shao, L-M., \& He, P-J. (2015). Quantification of regional leachate variance from municipal solid waste landfills in China. Waste Management, 46, 362-372.

https://doi.org/10.1016/..wasman.2015.09.016

\section{General rights}

Copyright and moral rights for the publications made accessible in the public portal are retained by the authors and/or other copyright owners and it is a condition of accessing publications that users recognise and abide by the legal requirements associated with these rights.

- Users may download and print one copy of any publication from the public portal for the purpose of private study or research.

- You may not further distribute the material or use it for any profit-making activity or commercial gain

- You may freely distribute the URL identifying the publication in the public portal 


\section{Quantification of regional leachate variance from municipal solid waste landfills in China}

Na Yang ${ }^{a, c}$, Anders Damgaard ${ }^{b^{*}}$, Peter Kjeldsen ${ }^{b}$, Li-Ming Shao ${ }^{d}$, Pin-Jing He ${ }^{a^{*}, d}$

a State Key Laboratory of Pollution Control and Resource Reuse, Tongji University, 1239 Siping Road, Shanghai 200092, China

${ }^{b}$ Department of Environmental Engineering, Technical University of Denmark, 2800, Kongens Lyngby, Denmark

${ }^{\mathrm{c}}$ Shenzhen Academy of Environmental Sciences, 50 Honggui Road, Shenzhen 518001, China

${ }^{\mathrm{d}}$ Institute of Waste Treatment and Reclamation, Tongji University, 1239 Siping Road, Shanghai 200092, China

*Corresponding authors: solidwaste@tongji.edu.cn (He P.J.); adam@env.dtu.dk (Damgaard A.)

"NOTE: this is the author's version of a work that was accepted for publication in Waste Management \& Research journal. Changes resulting from the publishing process, such as peer review, editing, corrections, structural formatting, and other quality control mechanisms may not be reflected in this document. Minor changes may have been made to this manuscript since it was accepted for publication. A definitive version is published in Waste management, vol 46(4), pp 362-372, doi: 10.1016/j.wasman.2015.09.016" 


\begin{abstract}
The quantity of leachate is crucial when assessing pollution emanating from municipal landfills. In most cases, existing leachate quantification measures only take into account one source - precipitation, which resulted in serious underestimation in China due to its waste properties: high moisture contents. To overcome this problem, a new estimation method was established considering two sources: 1) precipitation infiltrated throughout waste layers, which was simulated with the HELP model, 2) water squeezed out of the waste itself, which was theoretically calculated using actual data of Chinese waste. The two sources depended on climate conditions and waste characteristics, respectively, which both varied in different regions. In this study, 31 Chinese cities were investigated and classified into three geographic regions according to landfill leachate generation performance: northwestern China (China-NW) with semi-arid and temperate climate and waste moisture content of about $46.0 \%$, northern China (China-N) with semi-humid and temperate climate and waste moisture content of about $58.2 \%$, and southern China (China-S) with humid and sub-tropical/tropical climate and waste moisture content of about 58.2\%. In China-NW, accumulated leachate amounts were very low and mainly the result of waste degradation, implying on-site spraying/irrigation or recirculation may be an economic approach to treatment. In China-N, water squeezed out of waste by compaction totaled $22-45 \%$ of overall leachate amounts in the first 40 years, so decreasing the initial moisture content of waste arriving at landfills could reduce leachate generation. In China-S, the leachate generated by infiltrated precipitation after HDPE geomembranes in top cover started failing, contributed more than $60 \%$ of the overall amounts over 100 years of landfilling. Therefore, the quality and placing of HDPE geomembranes in the top cover should be controlled strictly for the purpose of mitigation leachate generation.
\end{abstract}




\section{Graphical abstract}

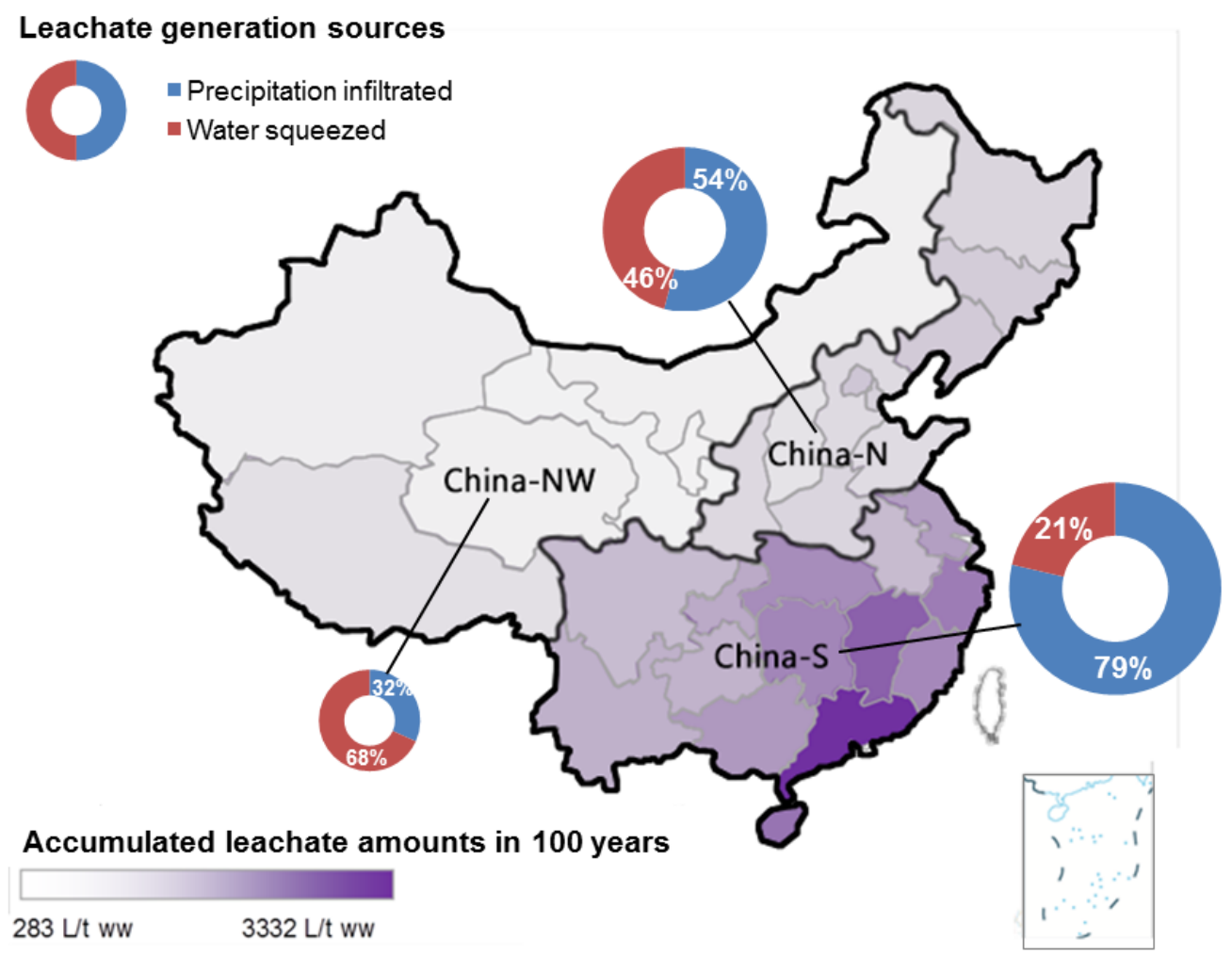

\section{Keywords}

Municipal solid waste, leachate generation, hydrological modeling, precipitation infiltration, waste water squeezing, regional variation

\section{Introduction}

Due to its economic advantages, landfilling is still the most dominant treatment method used worldwide for municipal solid waste (MSW), especially in developing countries such as China (National Bureau of Statistics of China, 2012). Leachate from MSW landfills is a threat to the quality of groundwater and surface waters (Kelly, 1976; Mor et al., 2006; Reinhard et al., 1984). Even though a series of leachate control systems may be installed in a landfill site, their performance is associated significantly with the amount of leachate generated, which is often underestimated in landfills in China (Lan et al., 2012) and results in an increased water head above the liner system, due to insufficient design capacities for collection and treatment. Subsequently, the high water level in a landfill body may lead 
potentially to leaching into the surrounding area and cause landfill instability. In addition, as the content of organic fractions in Chinese MSWs is usually high, the storage of water in a landfill may encourage the accumulation of acid and delay the arrival of the methanogenic phase, thereby making the landfill an "acid tomb" (He, 2009). In an "acid tomb", decaying carbon in the waste is most likely to be transferred into leachate rather than released as landfill gas, which aggravates the pollution loads and limits the energy recovery potential. Therefore, it is important to establish a leachate quantification method suitable for MSW landfills in China, to be able to control landfill pollution.

In addition to the control of leachate contamination, estimating landfill leachate quantities is also important in life cycle assessments (LCAs) of landfilling technology, as leachate is the origin of one of the most serious local environmental impacts. In LCA modelling for decision support, environmental impacts are normally modelled as the impact caused by one unit of waste (Banar et al., 2009; Cherubini et al., 2009; Hong et al., 2010), e.g. one tonne of waste or the waste generated in a defined geographical region in a given time (e.g. 1 year). This type of LCA modelling of landfill is often used for comparisons with other technologies (incineration, composting, etc.). However, existing methods in previous research (ElFadel et al., 1997) and in the Chinese national standards for landfill construction (Ministry of Housing and Urban-Rural Development of the People's Republic of China, 2013) were developed mainly to estimate leachate amounts generated from the entire landfill and with all the waste buried, in order to design leachate collection and treatment systems. In addition, most of the conventional LCA models (specific waste LCA models the exception (Gentil et al., 2010)) estimate the leachate quantities with default values without considering spatial and temporal variations. However, leachate generation amounts in different regions could vary a great deal, due to different climate conditions, waste properties.

Landfill leachate quantification is traditionally modeled based on water balance 
principles by summing the amounts of water entering the landfill and subtracting the amounts of water consumed by degradation and lost as water vapour (Blakey, 1992; ElFadel et al., 1997; Kjeldsen and Beaven, 2011). Accordingly, several mathematical models have been developed, in which Hydrologic Evaluation of Landfill Performance (HELP) model is most widely used for hydrological modeling of precipitation (Schroeder et al., 1994). The validation of existing HELP models were conducted for cover systems in tested field (Berger, 2015), which indicated that "the sum of measured lateral drainage and liner leakage is close to the sum of the corresponding simulated values" (overestimation by HELP model for $1.4 \%$ of the precipitation). However, the HELP model was questioned for leachate quantification in recent years because it neglected the water balance of waste, which was proved to be important processes during leachate generation. For instance, Komilis and Athiniotou (2014), Pantini et al. (2014) and Sao Mateus et al. (2012) established their own water budget models and demonstrated that water which leached out by waste compression and biodegradation contributed to the leachate amounts to a large extent. In China, researchers (Lan, et al. 2012; Yang, 2012b) widely believed that the failure to include water leaching out from waste itself in the Chinese national standard (Ministry of Housing and Urban-Rural Development of the People's Republic of China, 2013) was the main reason for the underestimation of leachate generation amounts in landfills.

In this study, an estimation approach for leachate generation per tonne of waste landfilled in China is developed. The influences of waste properties, climate conditions and top cover types on leachate generation are investigated, and regional values are suggested accordingly. Finally, suggestions are provided, to mitigate the leachate amounts in different geographic regions of China.

\section{Data Sources and Model Assumptions}

The water balance approach of a landfill used in this study is shown schematically in Figure 1. Leachate generated from MSW landfills can be divided 
into two sources: (1) precipitation infiltrated throughout waste layers (PI), which occurs in all types of landfill and lasts for the whole lifetime of the landfill, and (2) water squeezed out of waste itself by gravity and compaction, as well as degradation (WS), which occurs in the landfills receiving dumped waste with a high moisture and organics content. It should be notice that although water storage occurred in a real landfill, it was not considered in our simulation, as it is just the temporary situation for leachate in a long time scale (e.g. 100 years in this study). The amount of leachate can be calculated using eq.1. More details for each of the two parts can be found in Section 2.1 and Section 2.2.

$$
L=P I+W S
$$

where $L$ is the sum total of leachate generation. $L, P I$ and $W S$ are leachate quantities in litres per tonne of landfilled waste wet weight, $L \cdot t^{-1} w w$.

In order to verify the reliability of the leachate quantification method developed by this study, actual amounts of leachate - as measured in several landfill sites were obtained and compared with the estimated values.

\subsection{Infiltration from precipitation}

Leachate generated from infiltrated precipitation can be calculated by eq.2, which was established according mass balance theory.

$$
P I=\sum_{c}^{n} \frac{P \times\left(I_{c} / 100\right) \times t_{c}}{\rho \times h}
$$

where $P$ is precipitation at a locality, at $\mathrm{mm} \cdot \mathrm{year}^{-1} ; c$ means the top cover type in a landfill; $I_{c}$ is the ratio of precipitation infiltrated throughout waste layers with the top cover type of $c$, in \% terms; $t_{c}$ is the time period a top cover type of $c$ is utilised, in years; $\rho$ represents waste density in landfill, at $\mathrm{t} \cdot \mathrm{m}^{-3} ; h$ is the waste height in the landfill, in metres.

A generic landfill was established to calculate the amount of leachate associated with precipitation over a 100 year period after landfilling. In the landfill, a uniform height of $20 \mathrm{~m}$ of waste was assumed to be buried. After landfilling, waste 
density changed along with time due to compaction and degradation. The density of fresh waste and old waste were set as 0.8 and $1.3 \mathrm{t} \cdot \mathrm{m}^{-3}$, respectively (Qu et al., 2005). According to current Chinese national standards (Ministry of Housing and Urban-Rural Development of the People's Republic of China, 2013), four top cover types were investigated: daily cover (DC), intermediate cover (IC), unplanted final cover (UFC) and planted final cover (PFC). Based on a field survey by Ecobalance Inc. (1999), the timescales for the four types of top cover were set as follows: during the first 2 years after landfilling, the proportion of DC decreased from $100 \%$ to $0 \%$, whilst IC increased from $0 \%$ to $100 \%$; during 3-10 years after landfilling, the proportion of IC decreased from $100 \%$ to $0 \%$, whilst UFC increased from $0 \%$ to $100 \%$; over 10 years after landfilling, the top covers of the landfill were entirely set as PFC. The tensile strength of HDPE geomembranes decreases with its ageing, which may induce defects and influence the infiltration process. Accordingly, PFC were separated into two stages, i.e. with intact HDPE geomembranes (PFC-I) and with defective HDPE geomembranes (PFC-D). The service lifetime of HDPE geomembranes was likely more than 40 years according to Rowe (2011). To simulate the worst situation, PFC-I was assumed to be converted into PFC-D after 40 years of landfilling in this study.

The infiltration ratios of precipitation ending up as leachate $\left(I_{c}\right)$ are critical parameters for calculating PI, which are closely associated with regional climate conditions and landfill structures. In current Chinese national standard (Ministry of Housing and Urban-Rural Development of the People's Republic of China, 2013), $I_{c}$ are provided but are experience factors lacking practical verification. In this study, the specific $I_{c}$ under typical climate conditions with five different landfill top covers were obtained using the HELP model (Schroeder et al., 1994) (Visual HELP 2.2 was used in this study) by assessing the fates of precipitation in a landfill, namely evapotranspiration, runoff, collected leachate (i.e. leachate collected by the lateral drainage layers in the bottom liner system) and fugitive leachate (i.e. leachate 
percolated through the lowest layer of the bottom liner system). Considering the spatial variations in China, 31 locations were simulated, and each landfill was calculated using one city's weather parameters (one city per province, to represent China overall; the locations are shown in Figure 2, (the main weather data are shown in Figure S1 in Supporting Information). For each location, five different sets of data were calculated - each one with different landfill structures, as shown in Table 1. Buried waste and material properties are summarised in Table S1 and Table S2 in Supporting Information, respectively. Note that the initial moisture content (IMC) of the waste was set to the same as field capacity because water squeezed from waste was discussed as the other source of leachate generation (i.e. WS). For the purpose of minimising temporal uncertainties of climate conditions for the parameter $I_{c}$, accumulated leachate amounts over 100 years were obtained and divided by accumulated precipitation. To test for the robustness of the results, analyses of the critical parameters, i.e. runoff area factor, high-density polyethylene (HDPE) geomembrane defects, and HDPE geomembrane placement quality, were also performed, as shown in Table S3.

\subsection{Squeezed water from waste}

MSW landfilled in Western countries is believed to have the potential capacity to absorb water (Kjeldsen and Beaven, 2011), because its IMC is lower than the initial field capacity (IFC). Without considering the influence of precipitation and degradation, Zornberg et al. (1999) summarised the free liquid generation mechanism in three stages as a result of waste compression (the first three stages of waste with low IMC in Figure 3). Unlike waste in Western countries, the IMC of MSW in most Chinese regions is higher than the IFC. This means that when waste is unloaded at landfills, the extra liquid contained therein will drain away as a result of gravity. After mechanical compaction, followed by waste placement, the field capacity of the waste will decrease to a lower level, which is herein referred to as "field capacity after compaction" (FCC). Next, waste will decompose in the landfill 
body, during which time the field capacity of waste is reduced due to the decrease in dry matter of organic containing fractions. Finally, the "field capacity of aged waste" (FCA) is reached representing the final status of waste in landfills. Accordingly, waste undergoes four stages in total (see Stages "I/II/III/IV" in Figure 3) during landfilling. The differences between leachate mechanisms for waste with low and high IMCs are seen primarily between Stages I and II.

The first two processes (i.e. the two "compaction" processes for waste with low IMC and "gravity" and "compaction" processes for waste with high IMC) usually occur in weeks or months after waste is landfilled, during which waste decomposition is of minor importance and dry matter content of the waste remain relatively unchanged. For the sake of uniformity, the combined amount of leachate generated by those two processes, namely water squeezed by compaction and gravity $\left(\mathrm{WS}_{\mathrm{C}}\right.$ ), could be calculated as the difference between the IMC and FCC (eq. 3).

$$
W S_{C}=I D M \times\left(I M C_{D M} / 100-F C C_{D M} / 100\right) \times 1000
$$

where $W S_{C}$ is the amounts of water squeezed by compaction and gravity from 1 tonne of raw waste, with a unit of $\mathrm{L} \cdot \mathrm{t}^{-1} \mathrm{ww}$; IDM represents the initial dry matter weight in 1 tonne of raw waste, which could be calculated as $I D M=1-I M C / 100$ with a unit of $\mathrm{t}^{-1} \mathrm{ww} ; I M C_{D M}$ is the initial moisture content based on the weight of dry matter, calculated by $I M C_{D M}=\frac{I M C}{1-I M C / 100}$ with a unit of \% of DM; $F C C_{D M}$ is field capacity after compaction based on the weight of dry matter, calculated by $F C C_{D M}=\frac{F C C}{1-F C C / 100}$ with a unit of \% of DM; IMC and FCC are with the unit of $\%$ of wet weight and 1000 is the constant used to convert the unit from tonne to litre, $\mathrm{L} \cdot \mathrm{t}^{-1}$.

The degradation process usually last for years depending on landfill conditions and the fractional composition of the waste. In this stage, water is lost in two ways, one is via the degradation process itself and released as vapour in the landfill gas; 
the remainder is released as leachate. For the former, the water loss was about 12.3 $\mathrm{L} \cdot \mathrm{t}^{-1} \mathrm{ww}$ according to the following estimations: $100 \mathrm{~m}^{3}$ of landfill gas were generated per tonne of typical Chinese MSW (Yang et al., 2013); 0.1 L of water was used for degradation (Burton et al., 2004) and $0.023 \mathrm{~L}$ of water was released as water vapour (at a temperature of $20^{\circ} \mathrm{C}$ ) (Kjeldsen and Beaven, 2011) for $1 \mathrm{~m}^{3}$ of landfill gas. These figures were negligible in comparison to the entire water loss during degradation, which is supported by Athinoitou et al. (2012). Therefore, leachate generation during degradation process, namely water squeezed by degradation $\left(\mathrm{WS}_{\mathrm{D}}\right)$, could be represented as the decrease of field capacity (or water holding capacity) calculated using eq.4.

$$
W S_{D}=\left(I D M \times F C C_{D M} / 100-D M A \times F C A_{D M} / 100\right) \times 1000
$$

where $W S_{D}$ is the amounts of water squeezed by degradation from 1 tonne of raw waste, with a unit of $\mathrm{L} \cdot \mathrm{t}^{-1} \mathrm{ww}$; DMA represents the dry matter weight of aged waste remaining from 1 tonne of raw waste, calculated by $D M A=\sum_{i}\left[I D M_{i} \times\left(1-D R_{i} / 100\right)\right]$ with a unit of $\mathrm{t} \cdot \mathrm{t}^{-1} \mathrm{ww}$. With regard to degradation levels, waste fraction compositions could be divided into three groups represented by $i$ : fast degradable (i.e. food waste), slow degradable (i.e. paper, wood and textile) and non-degradable (i.e. plastics, metal, slag and glass). $I D M_{i}$ is the initial dry matter weight of waste fraction $i$ in 1 tonne of raw waste, with a unit of $\mathrm{t}^{-\mathrm{t}^{-1} \mathrm{ww} .} D R_{i}$ represents the extent of degradation in relation to the three groups above, with a unit of $\%$ of wet weight. $F C A_{D M}$ is the field capacity of aged waste on a dry basis, calculated by $F C A_{D M}=\frac{F C A}{1-F C A / 100}$ with a unit of $\%$ of DM.

Waste properties used for the simulation of WS were summarised from a literature review (Table S4 in Supporting Information), including 1) initial moisture contents and composition fractions of MSWs in 16 Chinese cities (locations can be found in Figure 2) and 2) moisture contents of individual waste fractions in 10 of the aforementioned cities, which were used to calculate the dry basis distributions of 
the waste fraction groups. According to the regional location of those cities, the average values for IMCs of MSW, and the dry basis distribution of three waste fraction groups (i.e. fast, slowly and non-degradable), were calculated for China-NW, China-N and China-S (Table 2), respectively. The degradation extents $\left(D R_{i}\right)$ for fast degradable, slowly degradable and non-degradable fractions of the MSW were assumed to be $84 \%, 39 \%$ and $0 \%$, respectively, according to the study carried out by Barlaz (1998), where optimised anaerobic degradation processes were simulated individually for different degradable waste components.

In terms of MSW field capacity, a number of studies have been conducted on the relevance between compression and the field capacity of MSW (Table S5 in Supporting Information). As the bulk density of waste varies along with compression, the correlation between field capacities (FC) and bulk densities (BD) can be obtained through linear regression (Figure S3 in Supporting Information) with the fitting equation of $\mathrm{FC}=(59.6 \pm 2.5)-(12.9 \pm 2.3) \times \mathrm{BD}$. According to Chinese industrial standards (Ministry of Construction Development of the People's Republic of China, 2007), the bulk density of waste prior to the final top cover should be higher than $0.8 \mathrm{t} \cdot \mathrm{m}^{-3}$, with the help of daily and final compaction. Thus, field capacity after the compaction (FCC) of MSW in a Chinese landfill can be calculated as $49.3 \pm 4.4 \%$ on the basis of regression. As no recommended bulk density or generic field capacity of waste after degradation were given in the literature, the field capacity of aged waste (FCA) was considered as the lowest value in the linear regression range, which was $39.0 \pm 6.2 \%$.

\section{Results and Discussion}

\subsection{Quantification of leachate generated by infiltrated precipitation}

Figure 4 presents the infiltration ratios of precipitation ending up as leachate $\left(I_{c}\right.$, shortened as infiltration ratios) in 31 Chinese cities' landfills with the five types of top cover. Considering the profiles of both infiltration ratios and geographic locations (Figure 5), the 31 cities can be classified into three groups: (1) cities with 
annual precipitations of less than $400 \mathrm{~mm}$, representing those located in north-western China (China-NW), (2) cities with annual precipitations between 400 and $800 \mathrm{~mm}$, located in northern China (China-N), and (3) cities with annual precipitations of more than $800 \mathrm{~mm}$, located in southern China (China-S). The three geographic regions have different climate conditions: China-NW is semi-arid and temperate, China- $\mathrm{N}$ is semi-humid and temperate and China-S is humid with a sub-tropical/tropical climate.

The infiltration ratios in the three geographic regions were calculated as the average values of the cities in specific regions (Table 3). In China-NW, infiltration ratios in this respect were generally lower than the values in China-N and China-S. Moreover, the variation extents of the infiltration ratios among different top cover types were smaller than those in China-N and China-S. Taking Lanzhou as an example (Figure S2 in Supporting Information), the above phenomenon can be explained by the fact that most of the precipitation was lost by evapotranspiration, due to low relative humidity and high solar radiation. In China-N and China-S, $30.7 \%$ and $43.1 \%$ of precipitation would end up as leachate when DC are utilised in landfills, respectively, which is obviously higher than in China-NW. If IC is installed instead of DC, the infiltration ratios would decrease by around $10-24 \%$ in China-N and in China-S. UFC and PFC-I induced an additional $54-79 \%$ reduction for infiltration ratios in China- $\mathrm{N}$, whilst the mitigation rates were as high as $84-95 \%$ in China-S. In contrast to the situations in China-N and China-S, landfills in China-NW with PFC-I as the top cover cause lower infiltration ratios than those with UFC indicating the importance of vegetation for mitigating leachate generation in China-NW. For the PFC-D, the infiltration ratios were 1.6-4.5 times and 5.8-13 times higher than those for PFC-I in China-N and China-S, respectively. These figures imply that the installation and maintenance of HDPE geomembranes in landfills are important to mitigate leachate formation in China-N and China-S, and the mitigation effort was more effective in China-S than in China-N, directly 
correlated to the precipitation level.

According to current Chinese national standards (Ministry of Housing and Urban-Rural Development of the People's Republic of China, 2013), infiltration ratios were suggested for landfills covered by DC, IC and final covers. With regards to DC and IC, regional specific values were given on the basis of annual precipitations (Table 3). By contrast with the values simulated in this study, the infiltration ratios in China-NW (or the locations with the annual precipitation $\leqslant$ $400 \mathrm{~mm}$ ) were significantly higher in the Chinese national standard, which might overestimate the leachate quantities in China-NW. The infiltration ratios for the landfills with PFC-D in China-S were higher than the suggested values for final covers in the Chinese national standard. Since the placement and maintenance process for HDPE geomembranes have not been strictly operated so far, PFC-D may be common in many Chinese landfills. If a landfill site located in China-S was designed according to Chinese national standard, leachate generated from infiltrated precipitation would be underestimated due to the missing distinction of PFC-D from final covers.

Sensitivity analyses of the primary parameters used in HELP modelling are shown in Table S3, assessing the influence of runoff area factor (i.e. $0 \%, 50 \%$ and 100\%), HDPE geomembrane defects (2, 20 and 200 defects $\mathrm{ha}^{-1}$ ), and HDPE geomembrane placement quality (i.e. good, poor and bad/worst case). The impact of runoff area factor on leachate generation ratio was insignificant except for the situations with IC, where the infiltration rate fell from as high as $42 \%$ to $15 \%$ in China-S. Regarding practical experience in landfill construction performance, an artificial gradient was usually first created when the final cover was established. Hence, a runoff area factor of $0 \%$ was used in the cases of DC and IC, and the runoff area factor were set as $100 \%$ with the top cover types of UFC, PFC-I and PFC-D. HDPE geomembranes with 20 holes $\cdot \mathrm{ha}^{-1}$ performed similarly to those with 200 holes $\cdot$ ha $^{-1}$ in China-N and China-NW, whereas the infiltration doubled in China-S 
when going to 200 holes $\mathrm{ha}^{-1}$. To simulate the worst situations, we set the defect densities of HDPE geomembrane for PFC-D to 200 holes $\cdot \mathrm{ha}^{-1}$. It should be noted that the infiltration ratios with the defect densities of 20 and 200 holes $\cdot \mathrm{ha}^{-1}$ were significantly higher than the values suggested in the current Chinese national standard. The placement quality of HDPE geomembrane affected the infiltration ratio significantly for landfills with the top cover types of UFC and PFC-I. However, considering the practical installation conditions of HDPE geomembrane in most landfills in China, "poor" status wasset for all the profiles.

\subsection{Quantification of leachate generated by water squeezed out of the waste}

On the basis of eq. 3 and eq. $4, \mathrm{WS}_{\mathrm{C}}$ and $\mathrm{WS}_{\mathrm{D}}$ were calculated for the cities for which it was possible to obtain waste properties (Table S4, Supporting Information) and the results are presented in Table 4. The regional specific values for the three geographical regions were calculated by applying the average waste property values in Table 2. For cities located in China-NW, landfilled waste may not drain away water during the compaction process, due to the low initial moisture content being below field capacity, while approximately $256 \mathrm{~L}$ of water can leach out for 1 tonne of raw waste during complete degradation. Conversely for China-N and China-S, $175 \mathrm{~L}$ of water would leach due to the compaction, and an additional $250 \mathrm{~L}$ of water due to the degradation of the waste, showing the importance of including the squeezed water. There were just small differences between the regionals specific values for China-N and China-S, but there was a large regional variation in China-S (i.e. 62-349 $\mathrm{L} \cdot \mathrm{t}^{-1} \mathrm{ww}$ for $\mathrm{WS}_{\mathrm{C}}$ and 206-283 $\mathrm{L} \cdot \mathrm{t}^{-1} \mathrm{ww}$ for $\mathrm{WS}_{\mathrm{D}}$ ), which could be due to diverse living habits and climate conditions in the cites located in China-S and subsequent various waste properties.

\subsection{Accumulated leachate amounts generated over 100 years}

The accumulated leachate amounts over 100 years for one tonne of MSW landfilled in the 31 cities are presented in Figure 6. To illustrate temporal distribution, PI was allocated to four time periods with relevant top cover types, i.e. 
1 and 2 years (with top cover DC and IC), 3-10 years (with top cover IC and UFC), 11-40 years (with top cover PFC-I) and 41-100 years (with top cover PFC-D). As for $\mathrm{WS}_{\mathrm{C}}$ and $\mathrm{WS}_{\mathrm{D}}$, the city specific values could be used for the cities shown in Table 4, whilst the regional specific values were used for the other cities. The temporal distributions of $\mathrm{WS}_{\mathrm{C}}$ and $\mathrm{WS}_{\mathrm{D}}$ were not available due to the definition of eq.3 and eq.4.

In China-NW, leachate accumulated over 100 years was less than $600 \mathrm{~L} \cdot \mathrm{t}^{-1} \mathrm{ww}$, of which $\mathrm{WS}_{\mathrm{D}}$ made the dominant contribution. As degradation occurs over a long time after initial landfilling (usually in years), depending on the degradation condition in the specific landfill site, the management of $\mathrm{WS}_{\mathrm{D}}$ is difficult. Leachate quantities from PI were insignificant, as it may be absorbed by waste during compaction $\left(\mathrm{WS}_{\mathrm{C}}\right)$. Therefore, it may be unnecessary to construct leachate treatment facilities in a landfill site in China-NW. The most economical solution may be to drain leachate into nearby municipal wastewater treatment plants, spray/irrigate leachate on landfill surface or recirculate the leachate into the waste layers.

In the case of China-N, leachates generated from WS were significant, accounting for $40-63 \%$ of the overall amounts over 100 years. Considering $\mathrm{WS}_{\mathrm{C}}$, the values $(22-45 \%)$ were significantly higher than those of PI $(15-25 \%)$ in the first 40 years. This implies that decreasing the initial moisture content of landfilled waste could be an effective approach to reducing leachate generation in China-N cities, especially at the beginning of landfilling. One of the approaches employed to mitigate waste moisture content could be avoiding food waste being disposed of in landfills, which is being tested in Shanghai (Shanghai Municipal People's Government, 2014) and Guangzhou (Guangzhou Municipal People's Government, 2011) and can be extended to the cities in China-N.

In China-S, the amounts of leachate from each individual source were higher than in China-N. Long-term (i.e. after 40 years of landfilling) generation potential could be a severe problem, since leachate generated during this period contributed 
more than $60 \%$ of the overall amounts as a result of the ageing HDPE geomembranes in the top cover. This is worsened as the ageing of HDPE geomembranes in the liner system occurred at the same time or earlier, which led to more migration of leachate into groundwater. For example, $4-8 \%$ of the generated leachate after 40 years of landfilling could be released if this was the case (data were calculated by HELP modelling but are not included in this paper). Therefore, in China-S, the quality of HDPE geomembranes, either through manufacturing or placement, must be controlled strictly, in order to reduce leachate generation and release.

\subsection{Comparison with actual data in practical landfills}

To evaluate its reliability, the landfill leachate quantification method established in this study was applied to 20 real-world landfill sites (considered as "estimated" results) where on-site measured leachate amounts (considered as "actual" values) were available. The estimated values and the actual values were not the same by definition. The estimated values meant the accumulated leachate of one tonne of waste generated in the operating period from the first year to the year of gathering data (named "testing year"). The actual values represented the transient leachate amounts generated by waste with different ages in the landfill at the testing year. To achieve a data format consistent with the estimated values (i.e. leachate amounts generated by one tonne of waste), actual leachate amounts were computed by dividing the measured yearly leachate quantities by yearly waste disposal amounts in the testing year. In the case of estimated results, PI was computed as the accumulated values during operating period, whilst WS represented the overall amounts during the entire lifetime of the landfill (considered as 100 years). Since some locations of the 20 real-world landfills were not included in the 31 cities discussed above, the parameters of the cities located in the same province were utilised for estimation.

The comparison between the estimated results and the actual values is shown 
in Table 5. The actual values indicated that leachate amounts generated in landfills located at China-S were significantly higher than those located at China-N and China-NW with similar operating period, which confirmed the findings in Figure 6. In all of the 20 landfill sites investigated in this study, actual leachate amounts were higher than the estimated values of PI, which only accounted for precipitation associated leachate. This highlights the necessity of including squeezed water out of waste (WS) when estimating landfill leachate quantities in China. For the landfills located in China-N and China-NW, as well as those located in China-S with an operating period of more than 3 years, the estimated values of PI+WS were higher than the actual leachate amounts. This was reliable as the estimated WS represents the overall values during the entire lifetime of the landfill rather than the accumulated values during the operating period. In the case of the landfills located in China-S with an operating period of up to 3 years, this estimation method frequently underestimated leachate amounts, even taking WS into account. This may be attributed to the underestimation of $I_{c}$ in the first years after landfilling assuming DC and IC were operated following the instructions of Chinese national standard. However, this assumption may not always be true. The failure of effective DC and IC could induce higher $I_{c}$, especially in China-S where precipitation amounts were extremely high. Since on-site measurements of leachate quantities (actual values) were rare in China, the statistical reliability for the above conclusions was limited by sample size. Therefore, validating the reliability of this method should be repeated as new actual data is made available.

\section{Conclusion}

In this study, a leachate quantification method was established for MSW landfilling in China. Two leachate sources were calculated separately in this method, which were precipitation infiltrated throughout waste layers (PI) and water squeezed out of waste itself (WS). By utilising this method, leachate amounts generated from one tonne of MSW, landfilled for 100 years, were estimated for 31 cities located all 
over China. According to the results, Chinese cities were grouped into three geographic regions based on climate conditions, which were China-NW (northwestern China), China-N (northern China) and China-S (southern China).

The contribution of WS to overall leachate quantities were significant, especially for the cities located in China-N. Therefore, WS is a non-ignorable part when quantifying leachate amounts in China. This could also be possible for other countries where the initial moisture contents of MSW were higher than the landfill field capacity. From the aspect of leachate mitigation, avoiding food waste being disposed of in landfills could be an effective approach in China-N.

In China-NW, leachate quantities were significantly lower than those in other regions. Therefore, it may be unnecessary to construct leachate treatment facilities in a landfill site in China-NW. The possible solution may be to drain leachate into nearby municipal wastewater treatment plants, spray/irrigate leachate on landfill surface or recirculate the leachate into the waste layers. Another finding requiring special attention was that, the infiltration ratios of precipitation ending up as leachate for China-NW suggested by the current Chinese national standard were higher than the values obtained in this study. This may lead to the overestimation of leachate quantity in China-NW by utilising the current Chinese national standard.

In China-S, leachate generation was aggravated dramatically after 40 years landfilling because of the increased defects for HDPE geomembranes in top cover layers. Since the placement and maintenance process for HDPE geomembranes have not been strictly operated so far, defective HDPE geomembranes may occur frequently in many Chinese landfills. However, this was not taken into account in the current Chinese national standard, which may lead to underestimation of the precipitation-associated leachate amounts (as "PI" in this study). In addition, the quality of HDPE geomembranes, either through manufacturing or placement, must be controlled strictly in China-S in order to limit leachate generation amounts effectively. 


\section{Acknowledgement}

The research is supported by Collaborative Innovation Center for Regional Environmental Quality and partially finance-supported by National Basic Research Program of China (973 Program, No. 2012CB719801) and China 111 Project. 


\section{Tables}

Table 1 Setup parameters for the five datasets used in the HELP simulations ${ }^{\text {a }}$.

\begin{tabular}{|c|c|c|c|c|c|c|c|c|}
\hline $\begin{array}{l}\text { Landfill cover } \\
\text { types }\end{array}$ & Top cover structures ${ }^{b}$ & $\begin{array}{l}\text { Top } \\
\text { cover } \\
\text { slope }\end{array}$ & $\begin{array}{c}\text { Runoff } \\
\text { area factor }\end{array}$ & $\begin{array}{l}\text { Vegetatio } \\
\text { n class }\end{array}$ & $\begin{array}{c}\text { HDPE } \\
\text { geomembranes } \\
\text { defects }^{c}\end{array}$ & $\begin{array}{c}\text { HDPE } \\
\text { geomembrane } \\
\text { placement quality }\end{array}$ & Waste layer & Bottom liner systems ${ }^{a}$ \\
\hline $\begin{array}{l}\text { 1) Daily Cover } \\
\text { (DC) }\end{array}$ & $22.5 \mathrm{~cm}$ of loamy sand soil & $0 \%$ & $0 \%$ & Bare soil & $2 \mathrm{ha}^{-1}$ & poor & $\begin{array}{c}10 \mathrm{~m} \text { of crude } \\
\text { waste } \\
10 \mathrm{~m} \text { of aged waste } \\
\end{array}$ & \\
\hline $\begin{array}{l}\text { 2) Intermediate } \\
\text { Cover (IC) }\end{array}$ & $30 \mathrm{~cm}$ of clay & $0 \%$ & $0 \%$ & Bare soil & $2 \mathrm{ha}^{-1}$ & poor & $\begin{array}{l}5 \mathrm{~m} \text { of crude waste } \\
15 \mathrm{~m} \text { of aged waste }\end{array}$ & \\
\hline $\begin{array}{l}\text { 3) Unplanted } \\
\text { Final Cover } \\
\text { (UFC) }\end{array}$ & $\begin{array}{c}60 \mathrm{~cm} \text { of loamy soil } \\
30 \mathrm{~cm} \text { of gravel } \\
1.0 \mathrm{~mm} \text { of HDPE geomembrane } \\
25 \mathrm{~cm} \text { of clay }\end{array}$ & $\begin{array}{c}5 \% \\
(60 \mathrm{~m})^{\mathrm{d}}\end{array}$ & $100 \%$ & Bare soil & $2 \mathrm{ha}^{-1}$ & poor & $20 \mathrm{~m}$ of aged waste & $\begin{array}{c}30 \mathrm{~cm} \text { of gravel } \\
1.5 \mathrm{~mm} \text { of HDPE geomembrane }\end{array}$ \\
\hline $\begin{array}{l}\text { 4) Planted Final } \\
\text { Cover - Intact } \\
\text { (PFC-I) }\end{array}$ & $\begin{array}{c}\text { Well-planted grass } \\
60 \mathrm{~cm} \text { of loamy soil } \\
30 \mathrm{~cm} \text { of gravel } \\
1.0 \mathrm{~mm} \text { of HDPE geomembrane } \\
25 \mathrm{~cm} \text { of clay }\end{array}$ & $\begin{array}{c}5 \% \\
(60 \mathrm{~m})\end{array}$ & $100 \%$ & $\begin{array}{l}\text { Good } \\
\text { stand of } \\
\text { grass }\end{array}$ & $2 \mathrm{ha}^{-1}$ & poor & $20 \mathrm{~m}$ of aged waste & $1.5 \mathrm{~mm}$ of HDPE geomembrane \\
\hline $\begin{array}{l}\text { 5) Planted Final } \\
\text { Cover - } \\
\text { Defective } \\
\text { (PFC-D) }\end{array}$ & $\begin{array}{c}\text { Well-planted grass } \\
60 \mathrm{~cm} \text { of loamy soil } \\
30 \mathrm{~cm} \text { of gravel } \\
1.0 \mathrm{~mm} \text { of HDPE geomembrane }\end{array}$ & $\begin{array}{c}5 \% \\
(60 \mathrm{~m})\end{array}$ & $100 \%$ & $\begin{array}{l}\text { Good } \\
\text { stand of } \\
\text { grass }\end{array}$ & $200 \mathrm{ha}^{-1}$ & poor & $20 \mathrm{~m}$ of aged waste & \\
\hline
\end{tabular}


$25 \mathrm{~cm}$ of clay

${ }^{\text {a }}$ Evaporative zone depth was set to the Visual HELP default values for each location.

${ }^{b}$ Referring to Ministry of Housing and Urban-Rural Development of the People's Republic of China (2013). In this standard, geotextiles should be installed above and beneath the HDPE geomembrane for protection. As the geotextiles impact hardly on water percolation and drainage compared with other layers, geotextiles layers were not stated here for simplification. Additionally, this standard recommended two kinds of bottom liner systems, i.e. single liner system and double liner system. In this study, double liner system was utilised.

${ }^{\mathrm{c}}$ HDPE geomembrane defects represents two kinds of defects: pinhole density and installation defects density (see Table S2). In this study, the two kinds of defects were set to the same value and were described as one uniform term "HDPE geomembrane defects" for the sake of simplification. The values of "HDPE geomembrane defects" were set for the HDPE geomembranes liner in the top covers in the case of UFC, PFC-I and PFC-D, and in the bottom liner systems in all the five cases.

${ }^{\mathrm{d}}$ Data in parentheses represent the slope length of the landfill top cover.. 
Table 2 Relevant waste properties in three geographical regions in China ${ }^{a}$.

\begin{tabular}{cccc}
\hline & China-NW & China-N & China-S \\
\hline Initial moisture contents (\% of ww) & $(\mathrm{n}=3)^{\mathrm{b}}$ & $(\mathrm{n}=5)^{\mathrm{b}}$ & $(\mathrm{n}=8)^{\mathrm{b}}$ \\
\hline Fast degradable & $46.0 \pm 1.5$ & $58.2 \pm 4.1$ & $58.2 \pm 4.6$ \\
\hline Slowly degradable & $37.9 \pm 6.1^{\mathrm{c}}$ & $37.9 \pm 6.1$ & $(\mathrm{n}=7)^{\mathrm{b}}$ \\
Non-degradable & $25.1 \pm 5.2^{\mathrm{c}}$ & $25.1 \pm 5.2$ & $16.3 \pm 4.1$ \\
\hline
\end{tabular}

${ }^{a}$ Data in this table were calculated on basis of data in Table S4, Supporting information

${ }^{\mathrm{b}}$ The numbers of datasets used to obtain the values.

${ }^{\mathrm{c}}$ The values refer to those in China-N due to a lack of data for China-NW.

Table 3 Infiltration ratios of precipitation ending up as leachate in three Chinese geographic areas

(unit: \%)

\begin{tabular}{|c|c|c|c|c|c|c|}
\hline & \multicolumn{3}{|c|}{ This study } & \multicolumn{3}{|c|}{ Chinese national standard ${ }^{b}$} \\
\hline & China-NW ${ }^{\mathrm{a}}$ & China- $\mathrm{N}^{\mathrm{a}}$ & China-S $^{\mathrm{a}}$ & $\mathrm{AP}^{\mathrm{c}}<400 \mathrm{~m}$ & $\mathrm{AP}<800$ & $\mathrm{P} \geq 800 \mathrm{~mm}$ \\
\hline Daily Cover (DC) & $15.0 \pm 6.3$ & $30.7 \pm 6.2$ & $43.1 \pm 6.9$ & $40-55^{\mathrm{d}}$ & $50-70^{\mathrm{d}}$ & $70-80^{d}$ \\
\hline Intermediate Cover (IC) & $14.4 \pm 6.8$ & $25.5 \pm 5.8$ & $36.6 \pm 6.6$ & $16-33^{\mathrm{e}}$ & $20-42^{\mathrm{e}}$ & $28-48^{\mathrm{e}}$ \\
\hline $\begin{array}{c}\text { Unplanted Final Cover } \\
\text { (UFC) }\end{array}$ & $6.8 \pm 2.5$ & $7.3 \pm 0.6$ & $3.9 \pm 0.7$ & & & \\
\hline $\begin{array}{c}\text { Planted Final } \\
\text { Cover-Intact (PFC-I) }\end{array}$ & $5.1 \pm 2.4$ & $7.3 \pm 0.5$ & $3.9 \pm 0.7$ & & $10-20$ & \\
\hline Planted Final & & & & & & \\
\hline $\begin{array}{c}\text { Cover-Defective } \\
\text { (PFC-D) }\end{array}$ & $6.9 \pm 5.7$ & $23.5 \pm 6.5$ & $35.8 \pm 6.1$ & & & \\
\hline
\end{tabular}

${ }^{a}$ Annual precipitations in the cities located at China-NW, China-N and China-S were in the ranges of 178-429 mm, 415-631 mm, and 886-1832 mm, respectively

${ }^{\mathrm{b}}$ Referring to Ministry of Housing and Urban-Rural Development of the People's Republic of China (2013).

"AP represents "annual precipitation".

${ }^{\mathrm{d}}$ The infiltration ratios of precipitation ending up as leachate for landfills with DC are the suggestions for waste with organic matter content less than $70 \%$.

${ }^{\mathrm{e}}$ The infiltration ratios of precipitation ending up as leachate for landfills with IC are not given in the standard, but are suggested as $40-60 \%$ of the values for DC.

Table 4 Squeezed water from landfilled waste in Chinese cities due to gravity and compaction (WS $\left.\mathrm{W}_{\mathrm{C}}\right)$ and waste degradation $\left(\mathrm{WS}_{\mathrm{D}}\right)$ 


\begin{tabular}{|c|c|c|c|c|}
\hline $\begin{array}{c}\text { Geographical } \\
\text { regions }\end{array}$ & Cities & $\mathrm{WS}_{\mathrm{C}}\left(\mathrm{L} \cdot \mathrm{t}^{-1} \mathrm{ww}\right)$ & $\mathrm{WS}_{\mathrm{D}}\left(\mathrm{L} \cdot \mathrm{t}^{-1} \mathrm{ww}\right)$ & $\mathrm{WS}\left(\mathrm{L} \cdot \mathrm{t}^{-1} \mathrm{ww}\right)$ \\
\hline \multirow{4}{*}{ China-NW } & Lanzhou & -99 & -- & -- \\
\hline & Urumqi & -45 & -- & -- \\
\hline & Lhasa & -51 & -- & -- \\
\hline & Regional specific ${ }^{\mathrm{a}}$ & -65 & 321 & 256 \\
\hline \multirow{6}{*}{ China-N } & Harbin & 108 & -- & -- \\
\hline & Beijing & 276 & 212 & 488 \\
\hline & Qingdao & 131 & -- & -- \\
\hline & Shenyang & 247 & 220 & 467 \\
\hline & Tianjin & 111 & 283 & 394 \\
\hline & Regional specific $^{a}$ & 175 & 247 & 423 \\
\hline \multirow{9}{*}{ China-S } & Hefei & 62 & 283 & 345 \\
\hline & Wuhan & 82 & 266 & 348 \\
\hline & Chengdu & 158 & 276 & 434 \\
\hline & Chongqing & 349 & 206 & 555 \\
\hline & Shanghai & 185 & 259 & 444 \\
\hline & Suzhou & 225 & -- & -- \\
\hline & Hangzhou & 143 & 259 & 401 \\
\hline & Shenzhen & 205 & 232 & 438 \\
\hline & Regional specific $^{a}$ & 176 & 252 & 429 \\
\hline
\end{tabular}

a The regional specific values were calculated by applying the average waste property values in Table 2 . 
Table 5 Comparison of the actual and estimated leachate generation amounts in practical landfill sites

\begin{tabular}{|c|c|c|c|c|c|c|c|c|}
\hline \multirow[t]{2}{*}{ Number } & \multirow[t]{2}{*}{ Regions } & \multirow[t]{2}{*}{ City (Landfill site) } & \multirow{2}{*}{$\begin{array}{l}\text { Operating } \\
\text { period } \\
\text { (years) }\end{array}$} & \multirow{2}{*}{$\begin{array}{l}\text { Actual values } \\
\left(\mathrm{L} \cdot \mathrm{t}^{-1} \mathrm{ww}\right)\end{array}$} & \multicolumn{2}{|c|}{$\begin{array}{c}\text { Estimated values } \\
\qquad\left(\mathrm{L} \cdot \mathrm{t}^{-1} \mathrm{Ww}\right)\end{array}$} & \multirow{2}{*}{$\begin{array}{c}\text { Reference for actual } \\
\text { values }\end{array}$} & \multirow{2}{*}{$\begin{array}{c}\text { City with the } \\
\text { parameters referred for } \\
\text { estimated values }\end{array}$} \\
\hline & & & & & $\mathrm{PI}^{\mathrm{a}}$ & $\mathrm{PI}+\mathrm{WS}^{\mathrm{b}}$ & & \\
\hline 1 & China-NW & Yi’ning & 5 & 70 & 8.2 & 284 & (Lan, 2012) & Urumqi \\
\hline 2 & China-N & Beijing (Liulitun) & 3 & 400 & 30 & 518 & (Li et al., 2009) & Beijing \\
\hline 3 & China-N & Beijing (Beishenshu) & 11 & 167 & 70 & 558 & (Li et al., 2009) & Beijing \\
\hline 4 & China-N & Beijing (Anding) & 3 & 490 & 30 & 518 & (Lan, 2012) & Beijing \\
\hline 5 & China-N & Tangshan (Jianzigu) & 2 & 280 & 13 & 440 & (Lan, 2012) & Shijiazhuang \\
\hline 6 & China-N & Xi'an (Jiangcungou) & 8 & 230 & 37 & 464 & (Lan, 2012) & Xi'an \\
\hline 7 & China-S & Suzhou (Qizishan) & 1 & 830 & 20 & 498 & (Lan, 2012) & Suzhou \\
\hline 8 & China-S & Changzhou & 8 & 380 & 110 & 588 & (Lan, 2012) & Suzhou \\
\hline 9 & China-S & Shanghai (Laogang) & 5 & 400 & 77 & 521 & (Lan, 2012) & Shanghai \\
\hline 10 & China-S & Ningbo (Yinzhou) & 4 & 400 & 105 & 507 & (Lan, 2012) & Hangzhou \\
\hline 11 & China-S & Lishui (Wulinggen) & 2 & 950 & 60 & 462 & (Lan, 2012) & Hangzhou \\
\hline 12 & China-S & Nanchang (Maiyuan) & 14 & 320 & 225 & 653 & (Lan, 2012) & Nanchang \\
\hline 13 & China-S & Changsha (Qiaoyi) & 8 & 290 & 144 & 573 & (Yang, 2012a) & Changsha \\
\hline 14 & China-S & Guiyang (Gaoyan) & 10 & 190 & 102 & 475 & (Lan, 2012) & Guiyang \\
\hline 15 & China-S & Chongqing (Changshengqiao) & 3 & 800 & 85 & 640 & (He et al., 2007) & Chongqing \\
\hline 16 & China-S & Chengdu (Chang'an) & 18 & 400 & 113 & 547 & (Lan, 2012) & Chengdu \\
\hline 17 & China-S & Kunming (Xijiao) & 5 & 154 & 78 & 507 & (Wu, 2007) & Kunming \\
\hline 18 & China-S & Guangzhou (Xingfeng) & 10 & 330 & 287 & 725 & (Lan, 2012) & Shenzhen \\
\hline 19 & China-S & Shenzhen (Xiaping) & 15 & 454 & 299 & 736 & $\begin{array}{l}\text { (Shenzhen Habitation } \\
\text { and Environmental }\end{array}$ & Shenzhen \\
\hline
\end{tabular}




\begin{tabular}{|c|c|c|c|c|c|c|c|c|}
\hline & & & & & & & Committee, 2013) & \\
\hline 20 & China-S & Jiangmen (Datuicheshan) & 7 & 356 & 243 & 680 & (Zhang et al., 2009) & Shenzhen \\
\hline
\end{tabular}

Leachate generation amounts estimated by the method established in this study, but only accounting for one source, i.e. "PI" representing. precipitation infiltrated throughout waste layers.

${ }^{b}$ Leachate generation amounts estimated by the method established in this study, accounting for both sources, i.e. "PI" representing precipitation infiltrated throughout waste layers and "WS" representing water squeezed out of waste itself. 


\section{Figures}

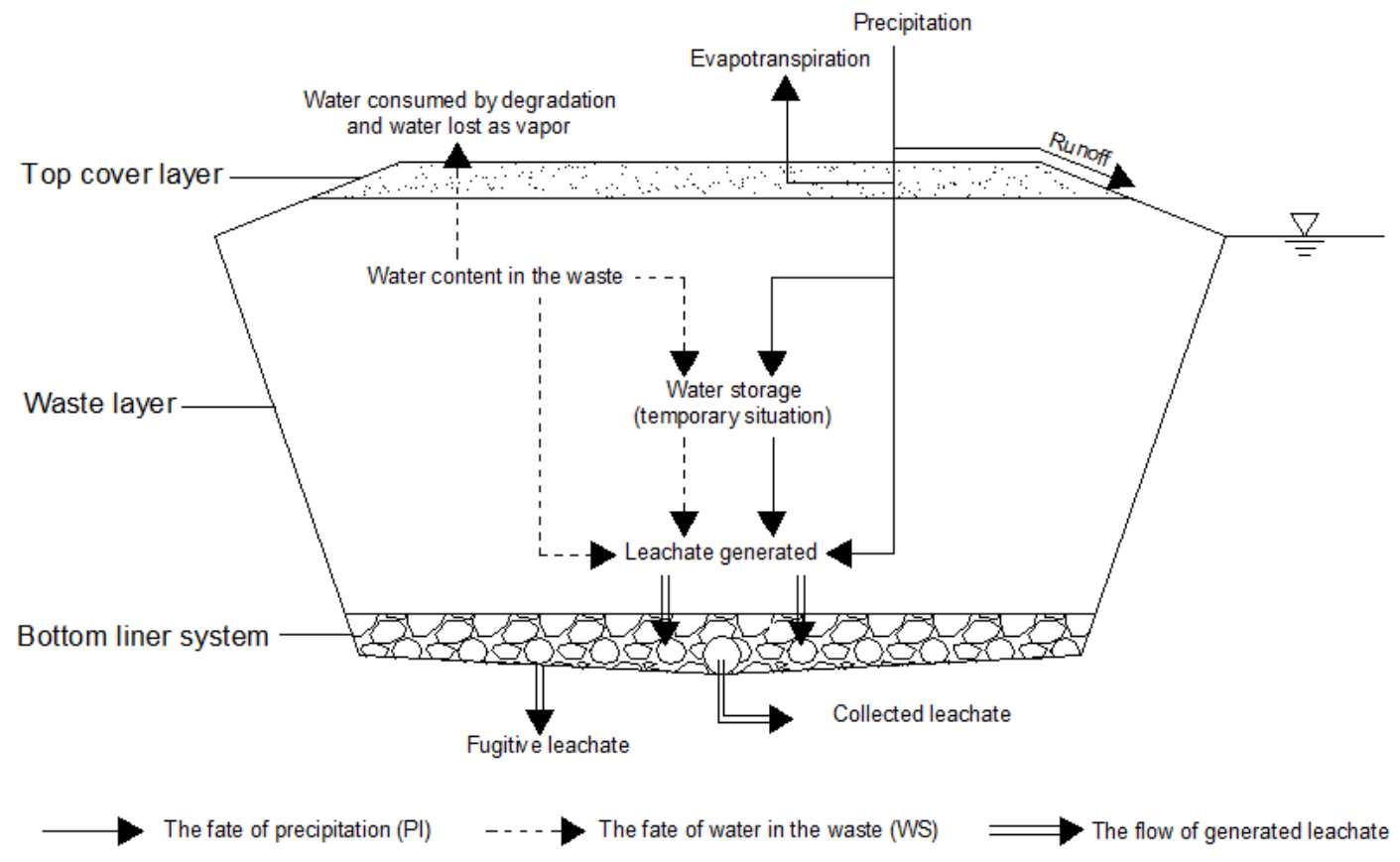

Figure 1 Schematic diagram of the water balance of a simulated landfill 


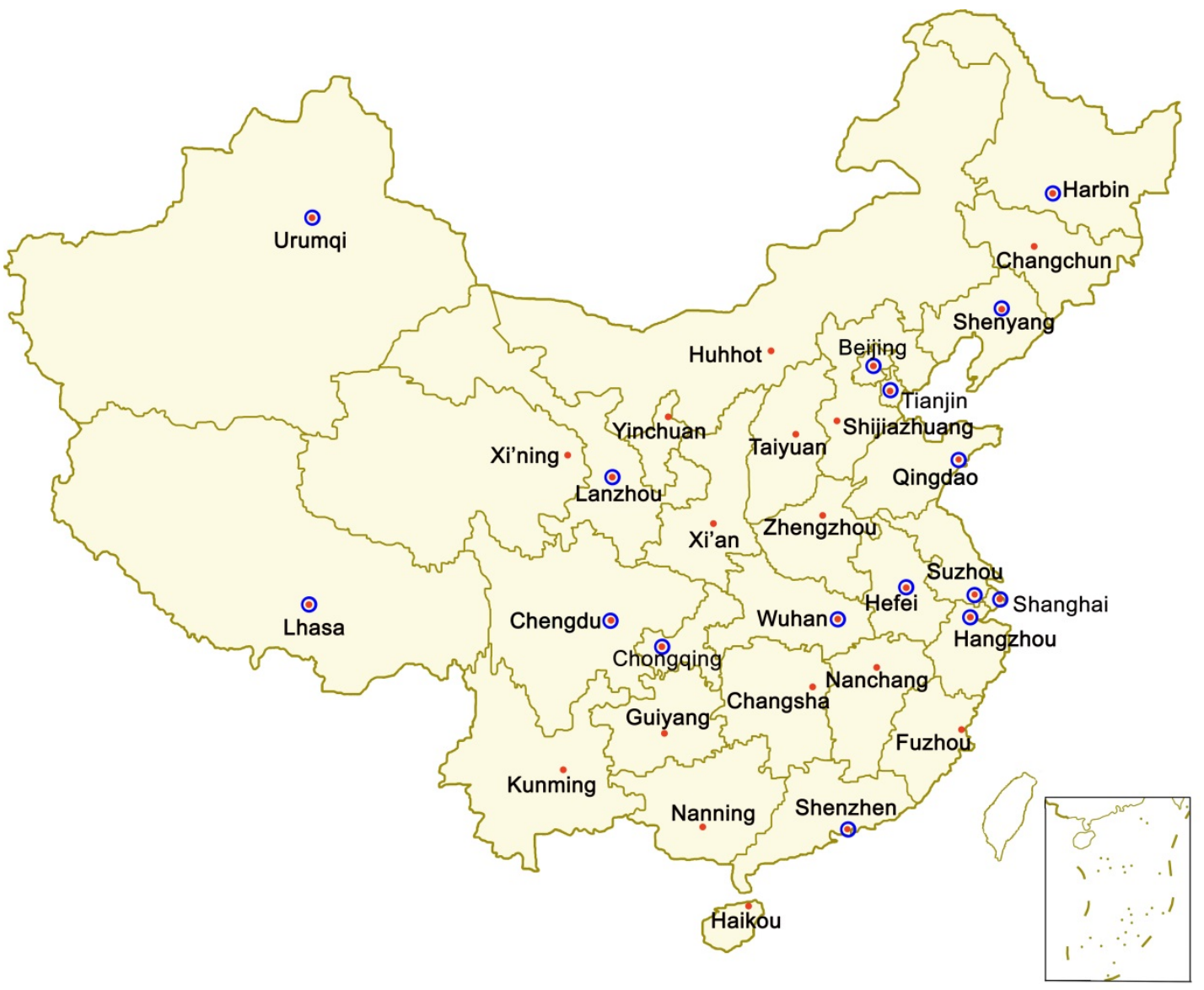

Figure 2 Cities where leachate generation by precipitation infiltration was simulated (red dots) and where waste compositions were obtained (blue circles) 


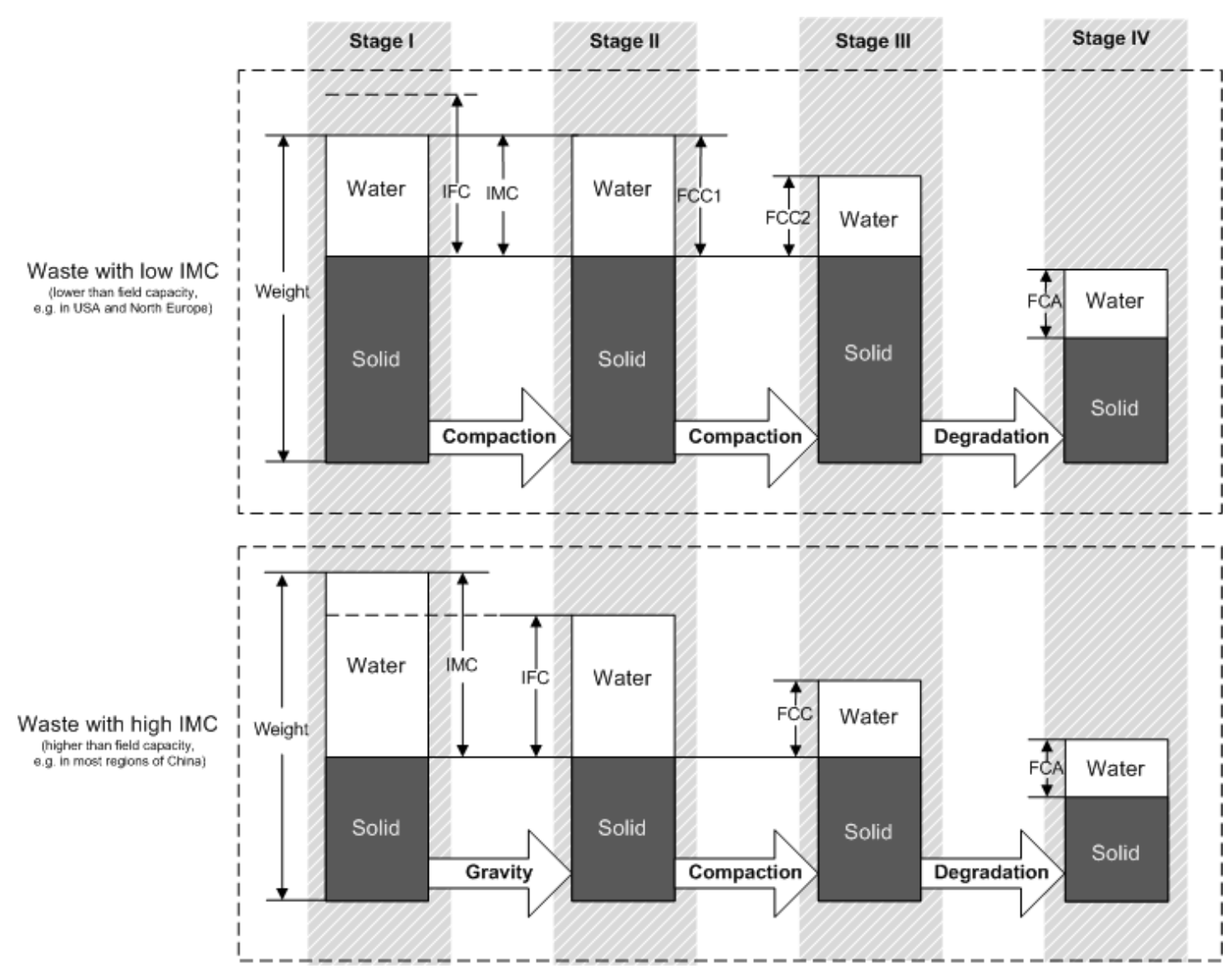

Figure 3 Schematic fate of water originally contained in waste during landfilling (IMC, Initial Moisture Content; IFC, Initial Field Capacity; FCC, Field Capacity after Compaction; FCA, Field Capacity of Aged waste. Stage I: The status of waste arriving at the landfill. Stage II: The status of waste when filled capacity is reduced to the same as the "IMC" through the compaction of waste with low IMC. The status of waste when its moisture content is reduced to the same as "IFC" by gravity for waste with high IMC; Stage III: The status of waste with the greatest physical compaction in the landfill body. Stage IV: The status of waste after complete degradation). 


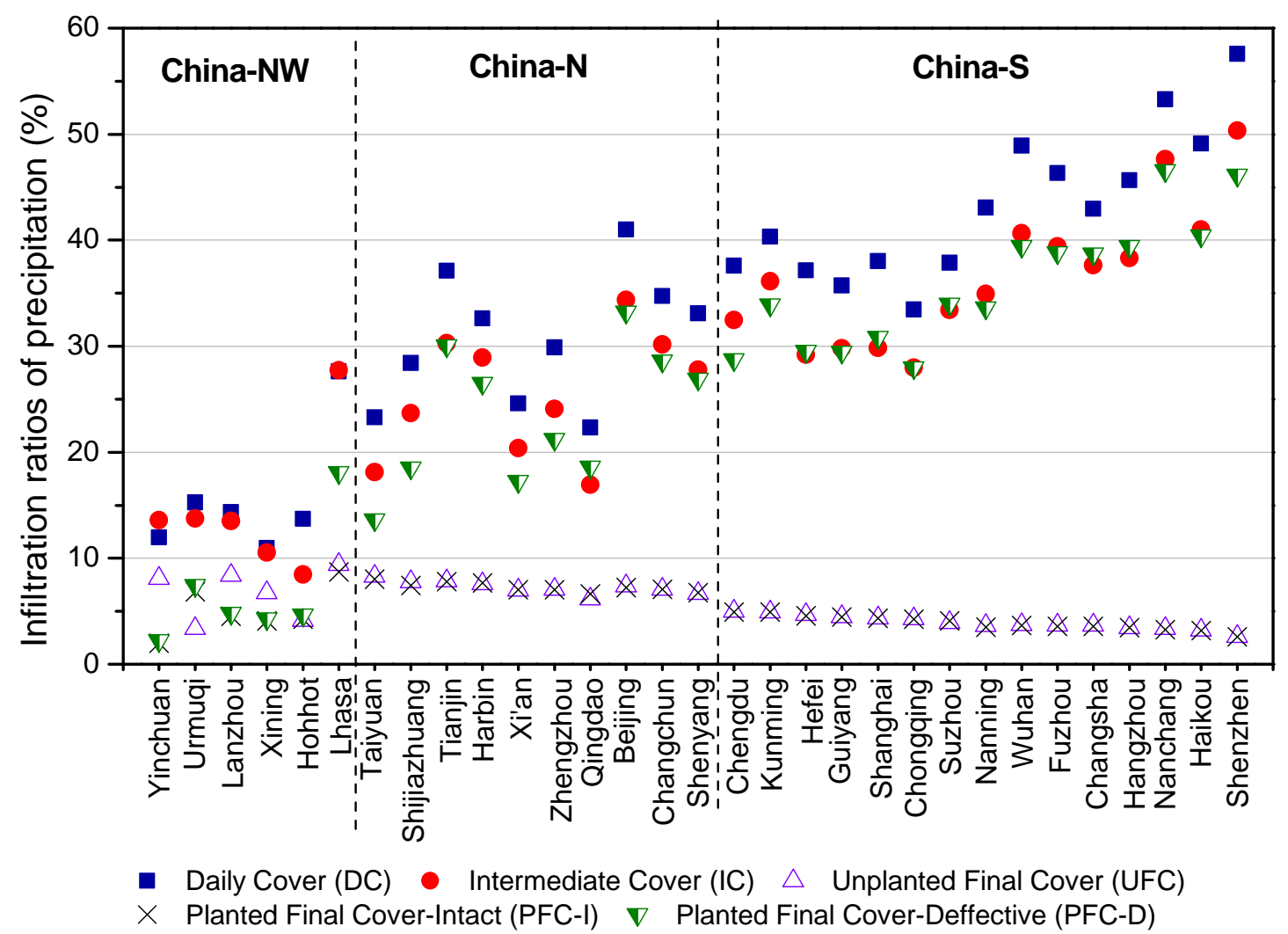

Figure 4 The infiltration ratios of precipitation ending up as leachate in 31 Chinese cities 


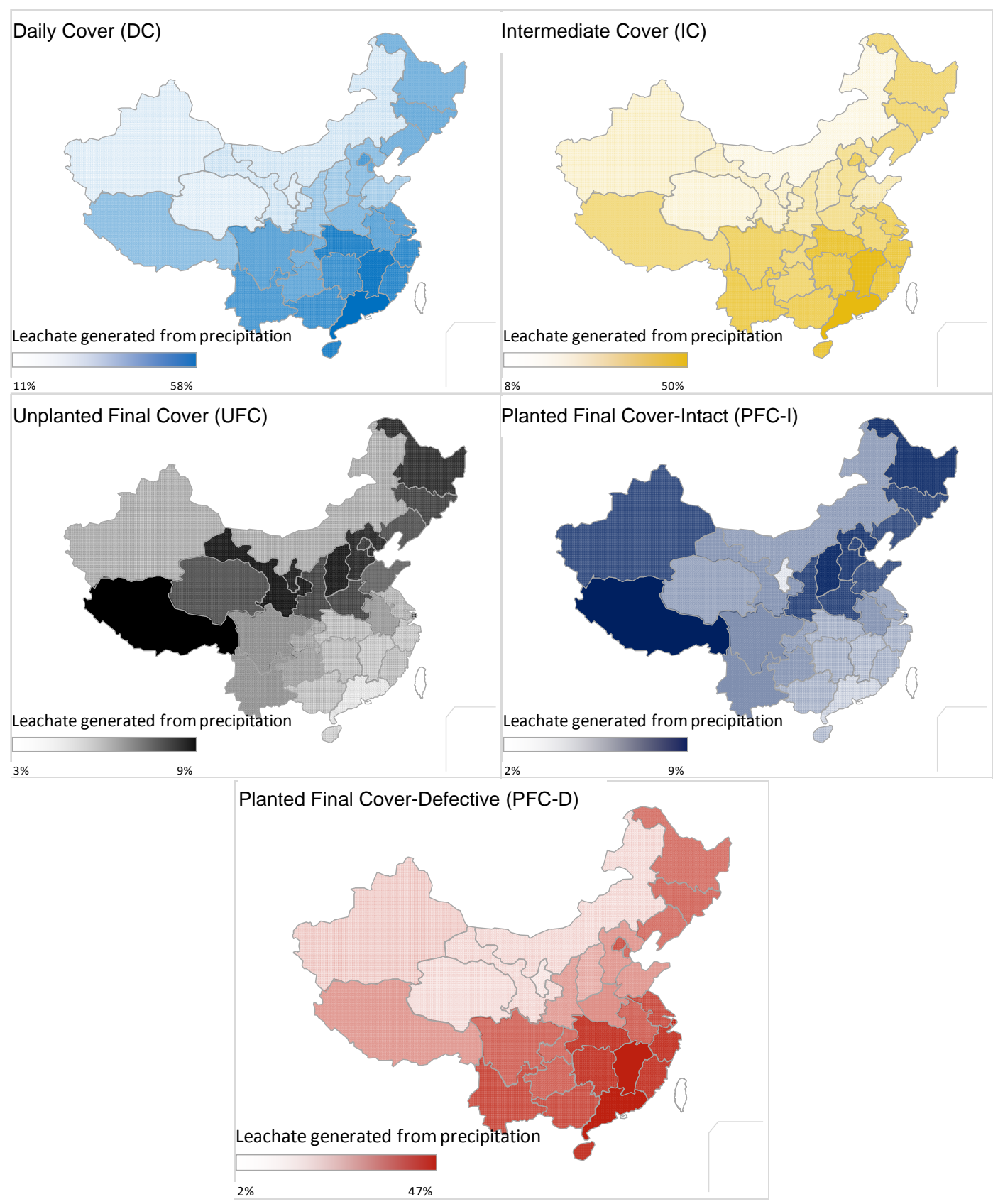

Figure 5 Geographic distributions of the infiltration ratios of precipitation ending up as leachate in China 


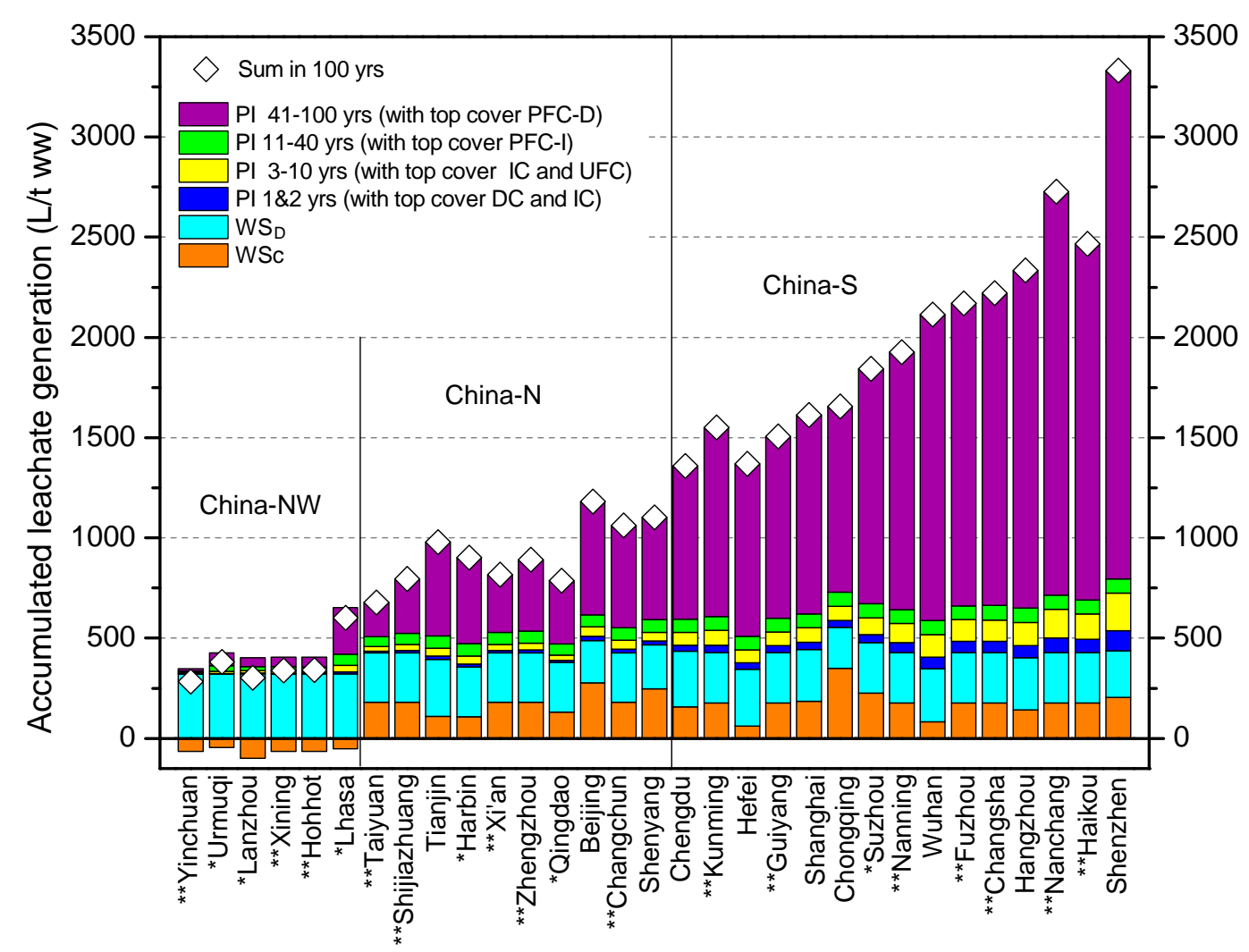

Figure 6 Accumulated leachate from different sources over 100 years. (For cities with “**” in front of their names, we used the average values of $\mathrm{WS}_{\mathrm{C}}$ and $\mathrm{WS}_{\mathrm{D}}$ for the relevant geographic regions. For cities with "**" in front of their names, we used the average values of $\mathrm{WS}_{\mathrm{D}}$ for the relevant geographic regions.).

\section{References}

Athiniotou, A., Papaspyros, I., Komilis, D., 2012. Modeling leachate generation from an active sanitary landfill. In: Proceedings of the $4^{\text {th }}$ international solid waste conference of the Hellenic Solid Waste Association, September, Athens, Greece.

Banar, M., Cokaygil, Z., Ozkan, A., 2009. Life cycle assessment of solid waste management options for Eskisehir, Turkey. Waste Manage. 29, 54-62.

Barlaz, M.A., 1998. Carbon storage during biodegradation of municipal solid waste components in laboratory-scale landfills. Global Biogeochem. Cycles 12, 373-380.

Berger U.K., On the current state of the Hydrologic Evaluation of Landfill Performance (HELP) model, Waste Manage. 38, 2015, 201-209.

Blakey, N.C., 1992. Model prediction of landfill leacahte production. In: Christensen, T.H., Cossu, R. and Stegmanne, R. (eds) Landfilling of Waste: Leachate. E\&FN Spon, London, UK, pp. 17-34.

Burton, S.A.Q., Beaven, R.P., White, J.K., 2004. The effect of moisture content in controlling landfill gas production and its application to a model for landfill 
refuse decomposition, Proceedings of the Waste 2004 Conference, Stratford upon Avon, UK, pp. 333-342.

Cherubini, F., Bargigli, S., Ulgiati, S., 2009. Life cycle assessment (LCA) of waste management strategies: Landfilling, sorting plant and incineration. Energy 34, 2116-2123.

Ecobalance Inc., 1999. Life cycle inventory of a modern municipal solid waste landfill. Environmental Research and Education Foundation, Washington DC.

ElFadel, M., Findikakis, A.N., Leckie, J.O., 1997. Modeling leachate generation and transport in solid waste landfills. Environ. Technol. 18, 669-686.

Gentil, E.C., Damgaard, A., Hauschild, M.Z., Finnveden, G., Eriksson, O., Thorneloe, S., Kaplan, P.O., Barlaz, M., Muller, O., Matsui, Y., Ii, R., Christensen, T.H., 2010. Models for waste life cycle assessment: review of technical assumptions. Waste Manag. 30, 2636-2648.

Guangzhou Municipal People's Government, 2011. Provisional regulations of Guangzhou city for management of municipal solid waste sorting (Guangzhou Government Decree No. 53), Guangzhou, China, (in Chinese).

He, P.J., 2009. Full-scale practicew of ecologically based landfill of municipal solid waste: to accelerate the biological conversion inside landfill and cover layers, in: Chen, Y.M., Tang, X.W., Zhan, L.T. (Eds.), Proceedings of the International Symposium on Geoenvironmental Engineering, ISGE 2009, September 8-10, Hangzhou, China, pp. 217-220.

He, Y.Q., Wang, Z.Y., Yang, J.P., 2007. Study on odor control measure by covering regulation tank in Changshengqiao waste sanitary landfill site of Chongqing,. Environmental Sanitation Engineering (In Chinese) 15, 15-16.

Hong, J.L., Li, X.Z., Cui, Z.J., 2010. Life cycle assessment of four municipal solid waste management scenarios in China. Waste Manage. 30, 2362-2369.

Kelly, W.E., 1976. Ground-Water Pollution Near a Landfill. Journal of the Environmental Engineering Division 102, 1189-1199.

Kjeldsen, P., Beaven, R., 2011. 10.3 Landfillling: Hydrology. In: Christensen, T.H. (ed), Solid Waste Technology \& Management. Blackwell Publishing Ltd., West Sussex, United Kingdom.

Komilis, D., Athiniotou, A., 2014. A water budget model for operating landfills: An application in Greece. Waste Manage. Res. 32(8):717-725.

Lan, J.W., 2012. Mechanism of leachate generation, transport and mound in MSW landfills and control of leachate level (in Chinese), Constructional Engineering. Zhejiang University, Hangzhou, China.

Lan, J.W., Zhan, L.T., Li, Y.C., Chen, Y.M., 2012. Impacts of initial moisture content of MSW waste on leachate generation and modified formula for predicting leachate generation. Environmental Science (in Chinese) 33, 1389-1395.

Li, R., Yue, D., Liu, J., Nie, Y., 2009. Size fractionation of organic matter and heavy metals in raw and treated leachate. Waste Manage. 29, 2527-2533.

Ministry of Housing and Urban-Rural Development of the People's Republic of China, 2013. Technical code for municipal solid waste sanitary landfill (GB50869-2013) (in Chinese), Chinese national standard. China Planning Press: , 
Beijing, China.

Ministry of Construction Development of the People's Republic of China, 2007. Technical code for municipal solid waste sanitary landfill closing (CJJ 112-2007) (in Chinese), Chinese industrial standard. China Architecture \& Building Press, Beijing, China.

Mor, S., Ravindra, K., Dahiya, R.P., Chardra, A., 2006. Leachate characterization and assessment of groundwater pollution near municipal solid waste landfill site. Environ. Monit. Assess. 118, 435-456.

National Bureau of Statistics of China, 2012. China statistical yearbook 2012 (in Chinese). China statistical press, Beijing, China.

Pantini, S., Verginelli, I., Lombardi, F., 2014. A new screening model for leachate production assessment at landfill sites. Int. J. Environ. Sci. Technol. 11:1503-1516.

Qu, X., He, P., Shao, L., Li, G., 2005. Research on hydraulic conductivity test of compacted municipal solid waste. Techniques and Equipment for Environmental Pollution Control (in Chinese) 6, 13-17.

Reinhard, M., Goodman, N.L., Barker, J.F., 1984. Occurence and distribution of organic chemicals in landfill leachate plumes. Environ. Sci. Technol. 18, 953-961.

Rowe, R.K., 2011. Systems engineering: the design and operation of municipal solid waste landfills to minimize contamination of groundwater. Geosynthetics International 18, 391-404.

Sao Mateus, M.D.S.C., Machado, S.L., Barbosa, M.C., 2012. An attempt to perform water balance in a Brazilian municipal colid waste landfill. Waste Manag. 32:471-481

Schroeder, P.R., Lloyd, C., Zappi, P., Aziz, N., 1994. The hydrologic evaluation of landfill performance (HELP) model. Engineering Dcumentation for Version 3, NTIS PB 95-212700. US EPA Office of Research and Development, Washington D.C.

Shanghai Municipal People's Government, 2014. Measures of Shanghai city for the promote of municipal solid waste sorting and reduction (Shanghai Government Decree No.14), Shanghai, China, (in Chinese).

Shenzhen Habitation and Environmental Committee, 2013. Shenzhen Environmental Quality Reports, Shenzhen, China, (in Chinese).

Wu, X.Z., 2007. Research on the treatment technologies of the waste landfill leachate: case study in Kunming. Hehai University, Nanjing, China, (in Chinese).

Yang, L., 2012a. Experimental study on the treatment of landfill leachate by the membrane bioreactor and reverse osmosis. Hunan University, Changsha, China, (in Chinese).

Yang, N., Zhang, H., Shao, L.M., Lyu, F., He, P.J., 2013. Greenhouse gas emissions during MSW landfilling in China: Influence of waste characteristics and LFG treatment measures. J. Environ. Manage. 129, 510-521.

Yang, W.B., 2012b. Feasibility study on a new estimate method for leachate from sanitary landfill. Hefei University of Technology, Hefei, China, (in Chinese).

Zhang, H.G., Chen, D.Y., Luo, D.G., Zhou, S.Q., 2009. Research on the 
pollution features of the organic substantces and heavy metals in landfill leachate. Journal of Shaanxi Technology university (in Chinese) 27, 86-89.

Zornberg, J.G., Jernigan, B.L., Sanglerat, T.R., Cooley, B.H. 1999. Retention of free liquids in landfills undergoing vertical expansion. Journal of Geotechnical and Geoenvironmental Engineering 125, 583-594.

\section{Supplementary material}

\section{Tables}

Table S1 Specific parameters for Chinese waste

\begin{tabular}{cccc}
\hline & Fresh waste & Old waste & Reference \\
\hline $\begin{array}{c}\text { Total porosity }\left(\mathrm{v} \cdot \mathrm{v}^{-1}\right) \\
\begin{array}{c}\text { Saturated hydraulic conductivity } \\
\left(\mathrm{cm} \cdot \mathrm{s}^{-1}\right)\end{array}\end{array}$ & 0.80 & 0.70 & $\begin{array}{c}\text { (Cao, 2007) } \\
(\text { Qu et al., 2005) }\end{array}$ \\
Field capacity $\left(\mathrm{w} \cdot \mathrm{w}^{-1}\right)$ & $0.45 \times 10^{-3 \mathrm{a}}$ & $3.1 \times 10^{-4 \mathrm{a}}$ & $\begin{array}{c}\text { (Ministry of Housing and } \\
\text { Urban-Rural Development of the } \\
\text { people's republic of China, 2012) } \\
\text { Default value in HELP model } \\
\text { Wilting point }\left(\mathrm{v} \cdot \mathrm{v}^{-1}\right)\end{array}$ \\
$\begin{array}{c}\text { (Schroeder et al., 1994) } \\
\text { Same as field capacity }\end{array}$
\end{tabular}

${ }^{a}$ Median values of the six results for fresh waste and 3-year-old waste excavated from the Laogang landfill site, respectively.

${ }^{\mathrm{b}}$ In this section, no absorption or leaking of water by the landfilled waste was considered. 
Table S2 Parameters of the materials used in the HELP model

\begin{tabular}{|c|c|c|c|c|c|c|}
\hline & Loamy sand soil & Loamy soil & Clay & $\begin{array}{c}\text { Moderately compacted } \\
\text { clay }\end{array}$ & Gravel & $\begin{array}{c}\text { HDPE } \\
\text { geomembrane }\end{array}$ \\
\hline Total porosity $\left(\mathrm{v}^{\cdot} \cdot \mathrm{v}^{-1}\right)$ & 0.437 & 0.463 & 0.475 & 0.451 & 0.397 & -- \\
\hline Field capacity $\left(\mathrm{v} \cdot \mathrm{v}^{-1}\right)$ & 0.105 & 0.232 & 0.378 & 0.419 & 0.032 & -- \\
\hline Wilting point $\left(\mathrm{v} \cdot \mathrm{v}^{-1}\right)$ & 0.047 & 0.116 & 0.265 & 0.332 & 0.013 & -- \\
\hline $\begin{array}{l}\text { Saturated hydraulic } \\
\text { conductivity }\left(\mathrm{cm} \cdot \mathrm{s}^{-1}\right)\end{array}$ & $1.7 \times 10^{-3}$ & $3.7 \times 10^{-4}$ & $1.7 \times 10^{-5}$ & $6.8 \times 10^{-7}$ & 0.3 & $1 \times 10^{-11 \mathrm{a}}$ \\
\hline Pinhole density $\left(\mathrm{ha}^{-1}\right)$ & -- & -- & -- & -- & -- & $2 / 200^{b}$ \\
\hline Installation defects $\left(\mathrm{ha}^{-1}\right)$ & -- & -- & -- & -- & -- & $2 / 200^{b}$ \\
\hline Placement quality & -- & -- & - & -- & -- & poor \\
\hline Utilisation & $\begin{array}{l}\text { As the barrier } \\
\text { layer in the daily } \\
\text { top cover }\end{array}$ & $\begin{array}{l}\text { As the plant } \\
\text { layer in the final } \\
\text { covers }\end{array}$ & $\begin{array}{l}\text { As the barrier layer } \\
\text { in the intermediate } \\
\text { top cover }\end{array}$ & $\begin{array}{l}\text { As the barrier layer in the } \\
\text { final covers and in the } \\
\text { bottom liner system }\end{array}$ & $\begin{array}{l}\text { As the drainage layers } \\
\text { in the final covers and } \\
\text { in the bottom liner } \\
\text { system }\end{array}$ & $\begin{array}{l}\text { As the } \\
\text { geomembrane liner } \\
\text { in the final covers } \\
\text { and in the bottom } \\
\text { liner system }\end{array}$ \\
\hline
\end{tabular}

\footnotetext{
${ }^{a}$ Referring to (Ministry of Construction of the People's Republic of China, 2006)
}

${ }^{\mathrm{b}}$ The pinhole density and installation defect density of HDPE geomembranes were set to the same value, and were described as HDPE geomembrane defects in Table 1. The pinhole density and installation defect density were set to $2 \mathrm{ha}^{-1}$ during service life (the first 40 years) as default values in the Visual HELP model. However, after service life (in the last 60 years), the value will increase due to the ageing of HDPE geomembranes. According to the sensitivity analyses (see Table S3), HDPE geomembranes with defects between 20 and $200 \cdot \mathrm{ha}^{-1}$ will induce similar leachate generation. To represent the worst situation in respect to aged HDPE geomembranes in this paper, the highest value $200 \cdot \mathrm{ha}^{-1}$ was chosen. 
Table S3 Sensitivity analyses of the parameters used in the HELP model

\begin{tabular}{|c|c|c|c|c|c|c|}
\hline & & \multicolumn{5}{|c|}{ Infiltration ratios of precipitation ending up as leachate } \\
\hline & & $\begin{array}{l}\text { Daily Cover } \\
\text { (DC) }\end{array}$ & $\begin{array}{l}\text { Intermediate Cover } \\
\text { (IC) }\end{array}$ & $\begin{array}{l}\text { Unplanted Final Cover } \\
\text { (UFC) }\end{array}$ & $\begin{array}{l}\text { Planted Final Cover-Intact } \\
\text { (PFC-I) }\end{array}$ & $\begin{array}{l}\text { Planted Final Cover-Defective } \\
\text { (PFC-D) }\end{array}$ \\
\hline \multirow[t]{13}{*}{1.} & Runoff area factor & & & & & \\
\hline & & \multicolumn{5}{|c|}{ Lanzhou (China-NW) } \\
\hline & $0 \%$ & $14.3 \% *$ & $13.5 \% *$ & $9.9 \%$ & $4.6 \%$ & $4.8 \%$ \\
\hline & $50 \%$ & $14.3 \%$ & $10.9 \%$ & $9.1 \%$ & $4.5 \%$ & $4.8 \%$ \\
\hline & $100 \%$ & $14.3 \%$ & $9.2 \%$ & $8.4 \% *$ & $4.5 \% *$ & $4.8 \% *$ \\
\hline & & \multicolumn{5}{|c|}{ Beijing (China-N) } \\
\hline & $0 \%$ & $41.0 \% *$ & $34.4 \% *$ & $8.5 \%$ & $8.4 \%$ & $35.0 \%$ \\
\hline & $50 \%$ & $41.0 \%$ & $20.1 \%$ & $7.5 \%$ & $7.3 \%$ & $34.1 \%$ \\
\hline & $100 \%$ & $41.0 \%$ & $12.0 \%$ & $7.4 \% *$ & $7.2 \% *$ & $33.2 \% *$ \\
\hline & & \multicolumn{5}{|c|}{ Shenzhen (China-S) } \\
\hline & $0 \%$ & $49.6 \% *$ & $42.1 \% *$ & $3.6 \%$ & $3.6 \%$ & $42.8 \%$ \\
\hline & $50 \%$ & $49.6 \%$ & $24.5 \%$ & $3.1 \%$ & $3.0 \%$ & $41.7 \%$ \\
\hline & $100 \%$ & $49.6 \%$ & $14.9 \%$ & $3.1 \% *$ & $3.0 \% *$ & $40.7 \% *$ \\
\hline
\end{tabular}

2. HDPE geomembrane defects

$$
\begin{aligned}
& 2 \mathrm{ha}^{-1} \\
& 20 \mathrm{ha}^{-1} \\
& 200 \mathrm{ha}^{-1} \\
& 2 \mathrm{ha}^{-1}
\end{aligned}
$$

Lanzhou (China-NW)

$$
\begin{gathered}
4.5 \% * \\
4.8 \% \\
4.8 \%
\end{gathered}
$$

Beijing (China-N) 


\begin{tabular}{|c|c|c|c|c|c|}
\hline & \multicolumn{5}{|c|}{ Infiltration ratios of precipitation ending up as leachate } \\
\hline & $\begin{array}{l}\text { Daily Cover } \\
\text { (DC) }\end{array}$ & $\begin{array}{l}\text { Intermediate Cover } \\
\text { (IC) }\end{array}$ & $\begin{array}{c}\text { Unplanted Final Cover } \\
\text { (UFC) }\end{array}$ & $\begin{array}{l}\text { Planted Final Cover-Intact } \\
\text { (PFC-I) }\end{array}$ & $\begin{array}{c}\text { Planted Final Cover-Defective } \\
\text { (PFC-D) }\end{array}$ \\
\hline $20 \mathrm{ha}^{-1}$ & & & & $29.0 \%$ & \\
\hline $200 \mathrm{ha}^{-1}$ & & & & $33.2 \%$ & \\
\hline & \multicolumn{5}{|c|}{ Shenzhen (China-S) } \\
\hline $2 \mathrm{ha}^{-1}$ & \multicolumn{5}{|c|}{$3.0 \% *$} \\
\hline $20 \mathrm{ha}^{-1}$ & \multicolumn{5}{|c|}{$21.7 \%$} \\
\hline $200 \mathrm{ha}^{-1}$ & \multicolumn{5}{|c|}{$40.7 \%$} \\
\hline \multicolumn{6}{|c|}{ 3. HDPE geomembrane placement quality } \\
\hline & \multicolumn{5}{|c|}{ Lanzhou (China-NW) } \\
\hline good & $14.3 \%$ & $13.6 \%$ & $3.0 \%$ & $2.4 \%$ & $4.5 \%$ \\
\hline poor & $14.3 \% *$ & $13.5 \% *$ & $8.4 \% *$ & $4.5 \% *$ & $4.8 \% *$ \\
\hline $\mathrm{bad} /$ worst case $^{\text {a }}$ & $14.3 \%$ & $13.5 \%$ & $8.8 \%$ & $4.8 \%$ & $4.8 \%$ \\
\hline & \multicolumn{5}{|c|}{ Beijing (China-N) } \\
\hline good & $41.0 \%$ & $34.4 \%$ & $1.8 \%$ & $1.8 \%$ & $31.8 \%$ \\
\hline poor & $41.0 \% *$ & $34.4 \% *$ & $7.4 \% *$ & $7.2 \% *$ & $33.2 \% *$ \\
\hline bad/worst case ${ }^{\text {a }}$ & $41.0 \%$ & $34.4 \%$ & $19.2 \%$ & $33.1 \%$ & $33.4 \%$ \\
\hline & \multicolumn{5}{|c|}{ Shenzhen (China-S) } \\
\hline good & $49.6 \%$ & $42.1 \%$ & $0.7 \%$ & $0.7 \%$ & $30.6 \%$ \\
\hline poor & $49.6 \% *$ & $42.1 \% *$ & $3.1 \% *$ & $3.0 \% *$ & $40.7 \% *$ \\
\hline bad/worst case ${ }^{\text {a }}$ & $49.6 \%$ & $42.1 \%$ & $22.8 \%$ & $37.9 \%$ & $40.9 \%$ \\
\hline
\end{tabular}

* These values are the results in the baseline scenario.

${ }^{a}$ In the Visual HELP online help, this status is called "bad placement quality". While it is called "worst case" in the user's manual. To avoid misunderstanding, these two terms are both shown here. 
Table S4 Initial moisture content and fraction compositions of municipal solid waste in 16 Chinese cities

\begin{tabular}{|c|c|c|c|c|c|c|c|c|c|c|c|}
\hline \multirow{2}{*}{ Regions } & \multirow{2}{*}{ Cities } & \multirow{2}{*}{$\begin{array}{c}\text { Initial moisture } \\
\text { contents, IMC (\% } \\
\text { of ww) }\end{array}$} & \multirow[b]{2}{*}{ Food wastes } & \multicolumn{6}{|c|}{ Fraction compositions $(\% \text { of } w w)^{a}$} & \multirow[b]{2}{*}{ Metals } & \multirow{2}{*}{ Reference } \\
\hline & & & & Papers & Plastics & Wood & Textiles & Slags & Glass & & \\
\hline China-NW & Lanzhou & 44.3 & 36.5 & 9.7 & 11.3 & 1.4 & 2.1 & 37.8 & 0.9 & 0.2 & $(\mathrm{Ji}, 2007)$ \\
\hline China-NW & Urumqi & 47.0 & 76.0 & 2.4 & 5.4 & 2.5 & 4.2 & 6.4 & 2.4 & 0.8 & (Shao et al., 2009) \\
\hline China-NW & Lhasa & 46.7 & 57.0 & 6.0 & 12.0 & 14.0 & 7.0 & 3.0 & 0.0 & 1.0 & (Jiang et al., 2009) \\
\hline China-N & Harbin & 54.8 & 44.8 & 13.4 & 3.3 & 0.0 & 4.7 & 24.5 & 6.6 & 2.7 & (Xie, 2009) \\
\hline China-N & Beijing & 63.3 & $66.2(82)$ & $10.9(29)$ & $13.1(33)$ & $3.3(22)$ & $1.2(22)$ & $3.9(12)$ & $1.0(\mathrm{NA})$ & $0.4(\mathrm{NA})$ & (Wang and Wang, 2013) \\
\hline China-N & Qingdao & 56.0 & 69.0 & 9.5 & 8.4 & 2.3 & 3.0 & 6.8 & 2.2 & 0.9 & (Jiang et al., 2011) \\
\hline China-N & Shenyang & 61.8 & $60.4(72)$ & $7.9(32)$ & 12.9 (NA) & $2.5(28)$ & $3.6(44)$ & $5.3(25)$ & 5.4(NA) & $2.1(\mathrm{NA})$ & (Gao et al., 2007; Ma, 2010) \\
\hline China-N & Tianjin & 55.0 & $56.9(65)$ & $15.3(48)$ & $16.9(44)$ & $1.6(40)$ & $3.9(47)$ & $2.9(14)$ & $1.6(2)$ & $0.7(9)$ & (He et al., 2010) \\
\hline China-S & Hefei & 52.3 & $61.5(64)$ & $1.9(61)$ & $11.4(33)$ & $0.9(27)$ & $2.1(36)$ & $21.7(34)$ & $0.6(\mathrm{NA})$ & 0.0 & (Jin, 2006) \\
\hline China-S & Wuhan & 53.5 & $55.3(66)$ & $1.5(43)$ & $4.5(49)$ & $8.3(49)$ & 0.0 & $27.3(36)$ & 2.0 (NA) & $1.1(\mathrm{NA})$ & $(\mathrm{Li}, 2010)$ \\
\hline China-S & Chengdu & 55.2 & $65.7(68)$ & $13(32)$ & $12(14)$ & $0.88(55)$ & $2.5(92)$ & $2.1(57)$ & $0.8(55)$ & $2.9(55)$ & (Huang and Liu, 2012) \\
\hline China-S & Chongqing & 58.7 & $53.7(76)$ & $13.6(68)$ & $16.3(59)$ & $4.9(73)$ & $6.2(66)$ & 0.0 (NA) & $3.8(13)$ & $1.1(5)$ & (Huang et al., 2003) \\
\hline China-S & Shanghai & 60.9 & $63.8(71)$ & $11.1(36)$ & $17.2(43)$ & $1.1(48)$ & $2.6(37)$ & $1.1(25)$ & $2.7(11)$ & $0.4(7)$ & (Zhang et al., 2009) \\
\hline China-S & Suzhou & 60.7 & 62.6 & 10.9 & 18.6 & 0.9 & 4.2 & 0.7 & 2.0 & 0.2 & (He et al., 2008) \\
\hline China-S & Hangzhou & 56.5 & $64.5(71)$ & $6.7(26)$ & $10.1(13)$ & $0.1(27)$ & $1.2(43)$ & $15.1(49)$ & $2.0(0)$ & $0.3(2)$ & (Zhuang et al., 2008) \\
\hline China-S & Shenzhen & 49.9 & $51.6(64)$ & $17.2(32)$ & $21.8(52)$ & $3.9(48)$ & $2.7(48)$ & $0.8(1)$ & $2.1(2)$ & $0.42(4)$ & $\begin{array}{c}\text { (Shenzhen Environmental } \\
\text { Sanitary Management }\end{array}$ \\
\hline
\end{tabular}


"NA" represents "not available." " Values in parentheses represent the moisture content of the specific waste fractions in \% of wet weight.

Table S5 Summarisation for the field capacities of waste in the existing literature

\begin{tabular}{|c|c|c|c|c|c|}
\hline Waste types used for testing & $\begin{array}{l}\text { Initial bulk density } \\
\qquad\left(\mathrm{t} \cdot \mathrm{m}^{-3}\right)\end{array}$ & $\begin{array}{l}\text { Initial moisture content } \\
\text { ( } \% \text { of wet weight })\end{array}$ & $\begin{array}{l}\text { Bulk density at field } \\
\text { capacity }\left(\mathrm{t} \cdot \mathrm{m}^{-3}\right)\end{array}$ & $\begin{array}{l}\text { Field capacity } \\
(\% \text { wet weight })\end{array}$ & Reference \\
\hline $4000 \mathrm{~m}^{3}$ crude MSW & 0.66 & $25 \%$ & NA & $31.8 \%{ }^{\mathrm{a}, \mathrm{b}}$ & $\begin{array}{c}\text { (Campbell, 1982; Kjeldsen and } \\
\text { Beaven, 2011) }\end{array}$ \\
\hline $4000 \mathrm{~m}^{3}$ crude MSW & 0.95 & $25 \%$ & NA & $28.0 \%{ }^{\mathrm{a}, \mathrm{b}}$ & $\begin{array}{c}\text { (Campbell, 1982; Kjeldsen and } \\
\text { Beaven, 2011) }\end{array}$ \\
\hline $4000 \mathrm{~m}^{3}$ crude MSW & 1.00 & $25 \%$ & NA & $26.8 \%{ }^{a, b}$ & $\begin{array}{c}\text { (Campbell, 1982; Kjeldsen and } \\
\text { Beaven, 2011) }\end{array}$ \\
\hline $6 \mathrm{~m}^{3}$ crude MSW & 0.40 & $15 \%$ & NA & $36.6 \%{ }^{\mathrm{a}, \mathrm{b}}$ & $\begin{array}{c}\text { (Campbell, 1982; Kjeldsen and } \\
\text { Beaven, 2011) }\end{array}$ \\
\hline $8 \mathrm{~m}^{3}$ pulverised MSW & NA & $40 \%$ & NA & $51.0 \%{ }^{\mathrm{a}}$ & $\begin{array}{l}\text { (Kjeldsen and Beaven, 2011; } \\
\text { Robinson et al., 1981) }\end{array}$ \\
\hline $6 \mathrm{~m}^{3}$ crude MSW & 0.5 & $35 \%$ & $0.71^{\mathrm{a}}$ & $54.4 \%$ & $\begin{array}{c}\text { (Kinman et al., 1982; Kjeldsen and } \\
\text { Beaven, 2011) }\end{array}$ \\
\hline $0.2 \mathrm{~m}^{3}$ pulverised MSW & 0.76 & $26 \%$ & $0.98^{\mathrm{a}}$ & $42.6 \%{ }^{\mathrm{a}}$ & $\begin{array}{c}\text { (Blakey, 1982; Kjeldsen and } \\
\text { Beaven, 2011) }\end{array}$ \\
\hline Indoor lysimeter crude MSW & 0.33 & $15 \%{ }^{\mathrm{a}}$ & $0.62^{\mathrm{a}}$ & $54.6 \%^{\mathrm{a}}$ & $\begin{array}{l}\text { (Fungarioli and Steiner, 1979; } \\
\text { Kjeldsen and Beaven, 2011) }\end{array}$ \\
\hline $9 \mathrm{~m}^{3}$ and $18 \mathrm{~m}^{3}$ crude MSW & 0.33 & $56 \%^{\mathrm{a}}$ & $0.45^{\mathrm{a}}$ & $68.0 \%^{\mathrm{a}}$ & $\begin{array}{l}\text { (Kjeldsen and Beaven, 2011; } \\
\text { Rovers and Farquhar, 1973) }\end{array}$ \\
\hline $0.2 \mathrm{~m}^{3}$ drums 17 -year-old MSW & 0.96 & $32 \%$ & $1.07^{\mathrm{a}}$ & $38.6 \%$ & (Holmes, 1980; Kjeldsen and \\
\hline
\end{tabular}


$0.2 \mathrm{~m}^{3}$ drums 17-year-old MSW

4 tonnes of crude domestic refuse

2.4 tonnes of pulverised MSW

6.5 tonnes of 20 -year-old waste

\begin{abstract}
$0.11 \mathrm{~m}^{3}$ of fresh waste
\end{abstract}
$0.14 \mathrm{~m}^{3}$ of fresh waste

$0.18 \mathrm{~m}^{3}$ of fresh waste

$0.13 \mathrm{~m}^{3}$ of fresh waste

$0.13 \mathrm{~m}^{3}$ of 0.5 -year-old waste

$0.13 \mathrm{~m}^{3}$ of 2-year-old waste

$0.13 \mathrm{~m}^{3}$ of 3-year-old waste

$0.13 \mathrm{~m}^{3}$ 6-year-old waste

Fresh waste with $90 \%$ paper and

$$
\text { cardboard }
$$

Various kinds of fresh waste

Various kinds of 1-year-old waste

Various kinds of 1-year-old waste

$$
0.04 \mathrm{~m}^{3} \text { of old waste }
$$

$\begin{array}{cc}0.64 & 32 \% \\ 0.49 & 34 \% \\ 0.36 & 29 \% \\ 0.91 & 42 \% \\ 0.2-0.5 & 12.5 \% \\ 0.2-0.5 & 21.3 \% \\ 0.2-0.5 & 16.5 \% \\ \text { NA } & \text { NA } \\ \text { NA } & \text { NA } \\ \text { NA } & \text { NA } \\ \text { NA } & \text { NA } \\ \text { NA } & \text { NA } \\ \text { NA } & \text { NA } \\ \text { NA } & \text { NA } \\ \text { NA } & \text { NA } \\ \text { NA } & \text { NA } \\ \text { NA } & \text { NA }\end{array}$

\section{$0.84^{\mathrm{a}}$}

$47.6 \%$

$0.79-1.16^{\mathrm{a}}$

$0.55-0.94^{\mathrm{a}}$

$1.09-1.43^{\mathrm{a}}$

$0.36-0.85^{\mathrm{a}}$

$0.6-0.61^{\mathrm{a}}$

$0.54-1.06^{\mathrm{a}}$

$0.98-1.23^{\mathrm{a}}$

$1.09-1.30^{\text {a }}$

$1.02-1.23^{\mathrm{a}}$

$1.04-1.10^{\mathrm{a}}$

$1.08-1.42^{\mathrm{a}}$

$1.01-1.72^{\mathrm{a}}$

$0.85-1.56^{\mathrm{a}}$

$0.93-1.62^{\mathrm{a}}$

$0.79-1.62^{\mathrm{a}}$

$0.88-1.18^{\mathrm{a}}$
Beaven, 2011)

(Holmes, 1980; Kjeldsen and

Beaven, 2011)

(Beaven, 1999)

(Beaven, 1999)

(Beaven, 1999)

(de Velasquez et al., 2003)

(de Velasquez et al., 2003)

(de Velasquez et al., 2003)

$$
\begin{aligned}
& \text { (Lan, 2012) } \\
& \text { (Lan, 2012) } \\
& \text { (Lan, 2012) } \\
& \text { (Lan, 2012) } \\
& \text { (Lan, 2012) }
\end{aligned}
$$

(Blight et al., 1992)

(Blight et al., 1992)

(Blight et al., 1992)

(Blight et al., 1992)

(Zornberg et al., 1999)

${ }^{\mathrm{a}}$ These data were not originally present in the literature but calculated by the authors from other existing parameters.

${ }^{b}$ Field capacity is calculated based on primary absorptive capacity, which is not the same as others based on total absorptive capacity. Therefore, these data are not used in the regression in Figure S5.

${ }^{\mathrm{c}}$ As waste with $90 \%$ paper and cardboard is not the typical MSW, these field capacities are not used in the regression in Figure S5. 


\section{Figures}
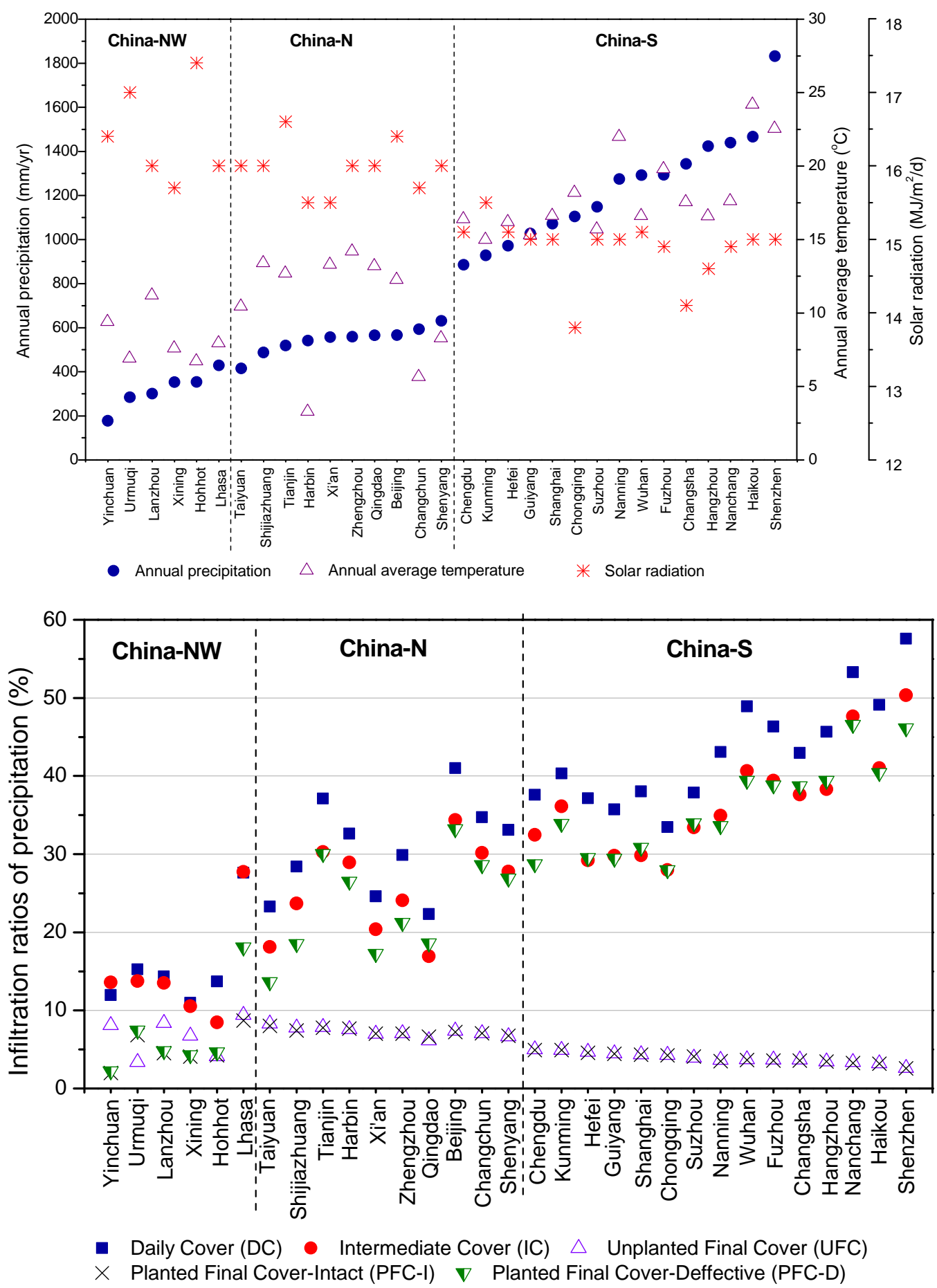

Figure S1 Weather parameters used in the HELP simulations and the infiltration ratios of precipitation ending up as leachate in 31 Chinese cities

(The weather data was created by the Weather Generator included in Visual HELP. The weather data of Harbin, Changchun, Chongqing and Changsha were not available in Weather Generator, the closest 
cities' weather datasets were used instead for calculation (i.e. Shenyang for Harbin and Changchun, Jinfushan for Chongqing, Yueyang for Changsha). However, the average monthly rainfall and average monthly temperature of the closest cities' weather datasets were replaced by the four cities' own parameters based on 30 years' data sources supplied by China Meteorological Administration.) 
Lanzhou

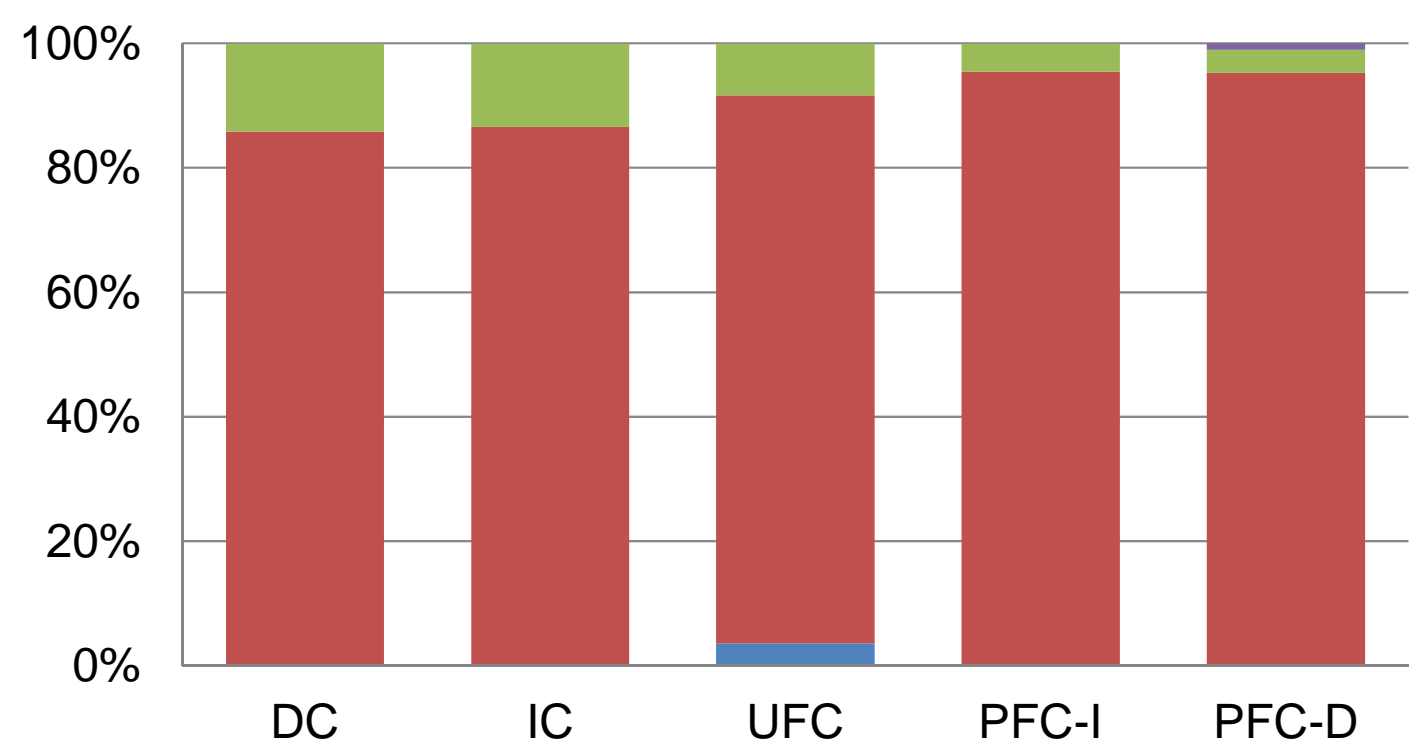

(a) China-NW

\section{Beijing}

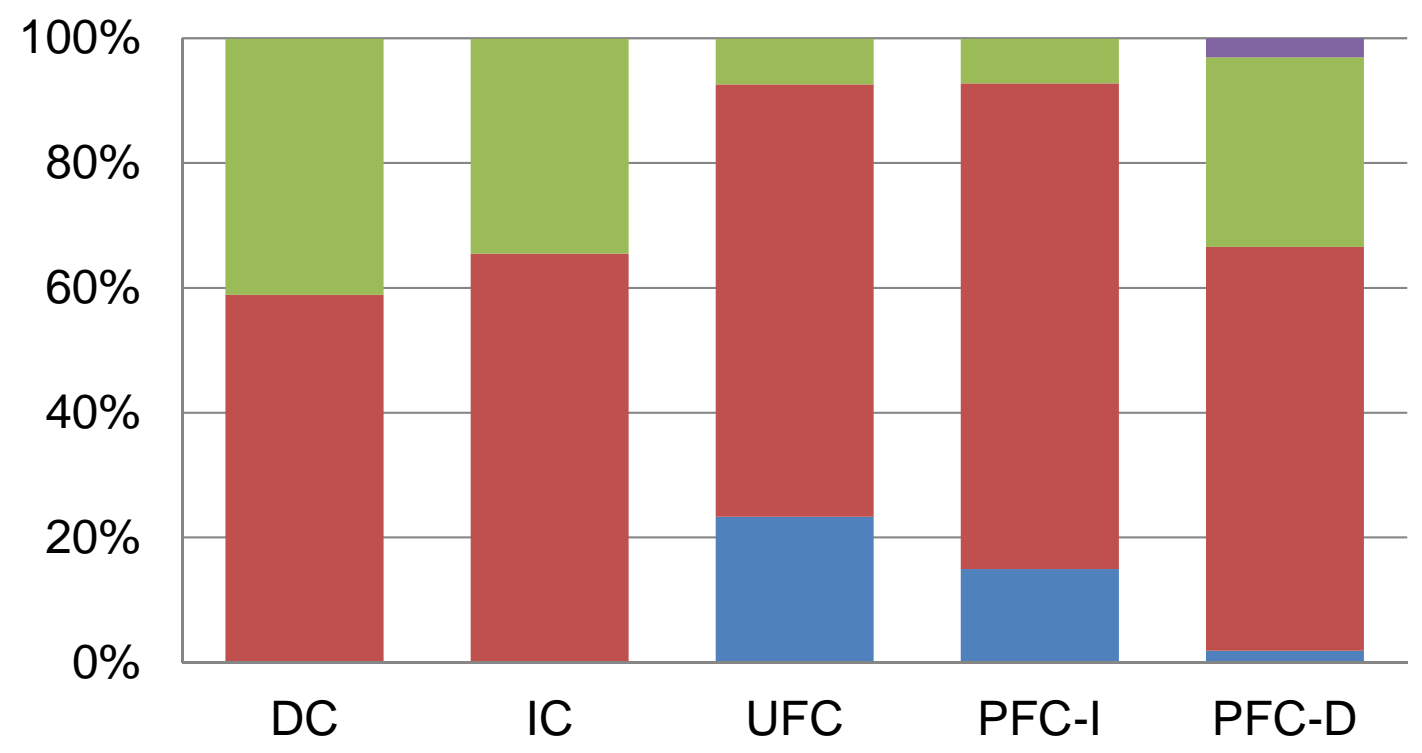

(b) China-N 


\section{Shanghai}

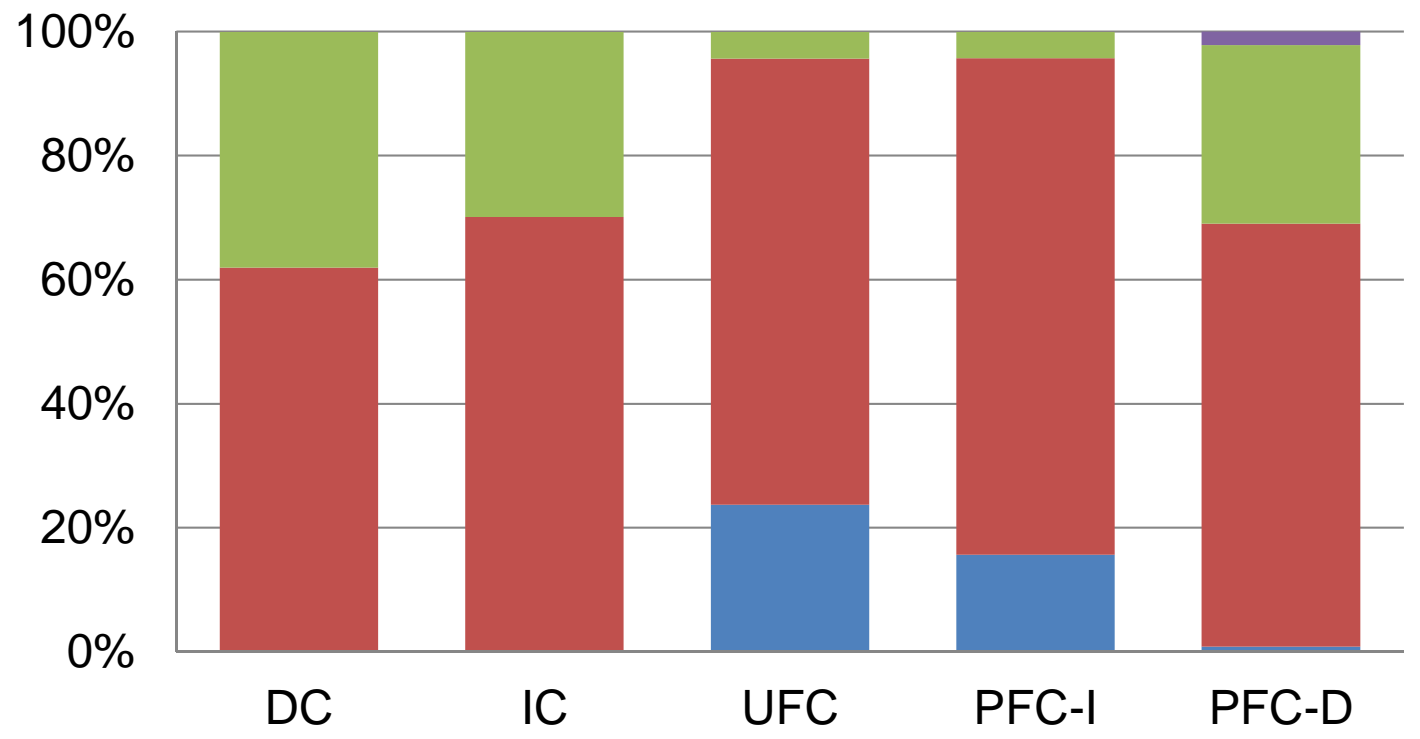

\section{Shenzhen}

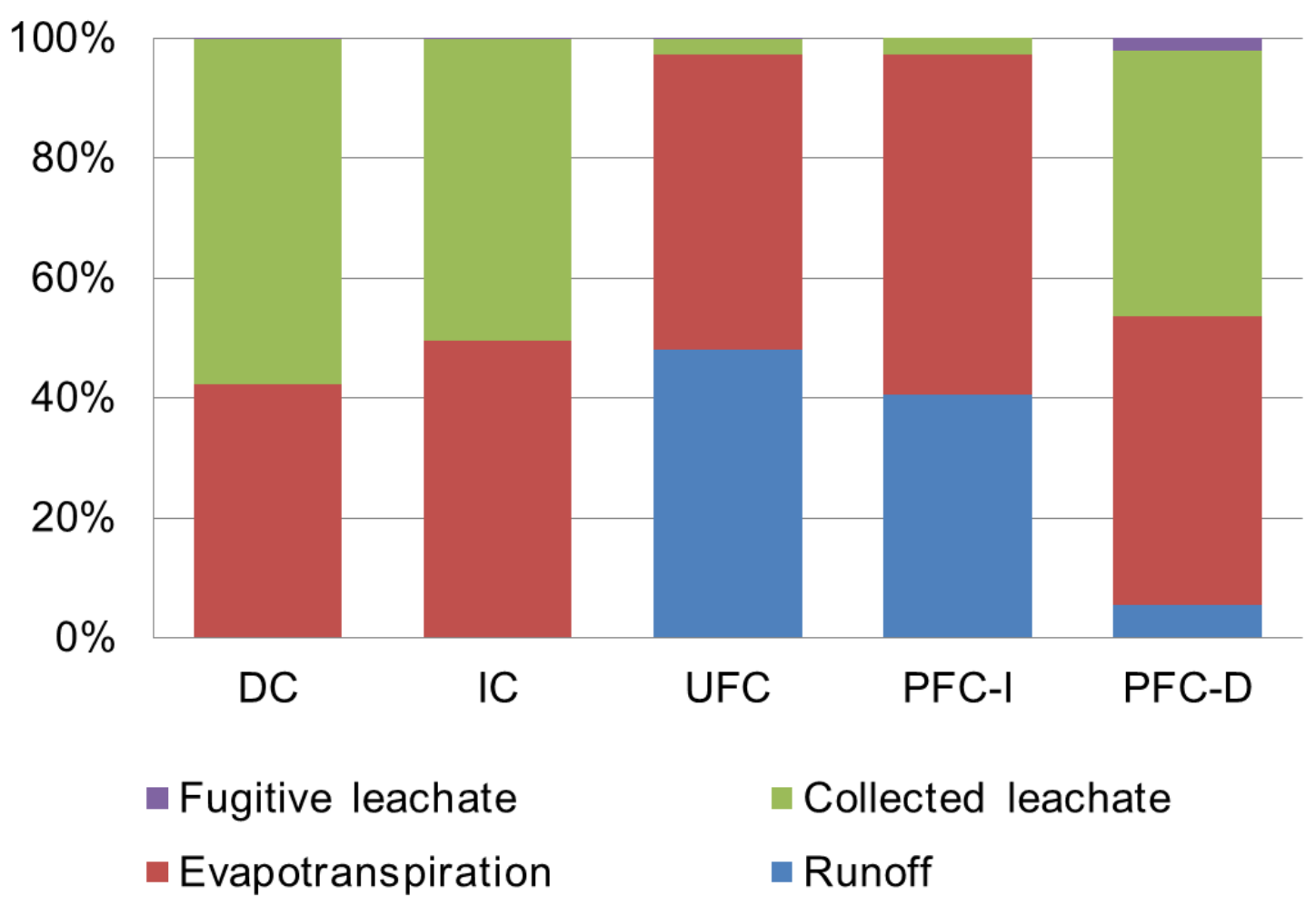

(c) China-S

Figure S2 Average yearly water balances in percent of precipitation at landfill sites under five types of top cover for the three Chinese geographic regions 


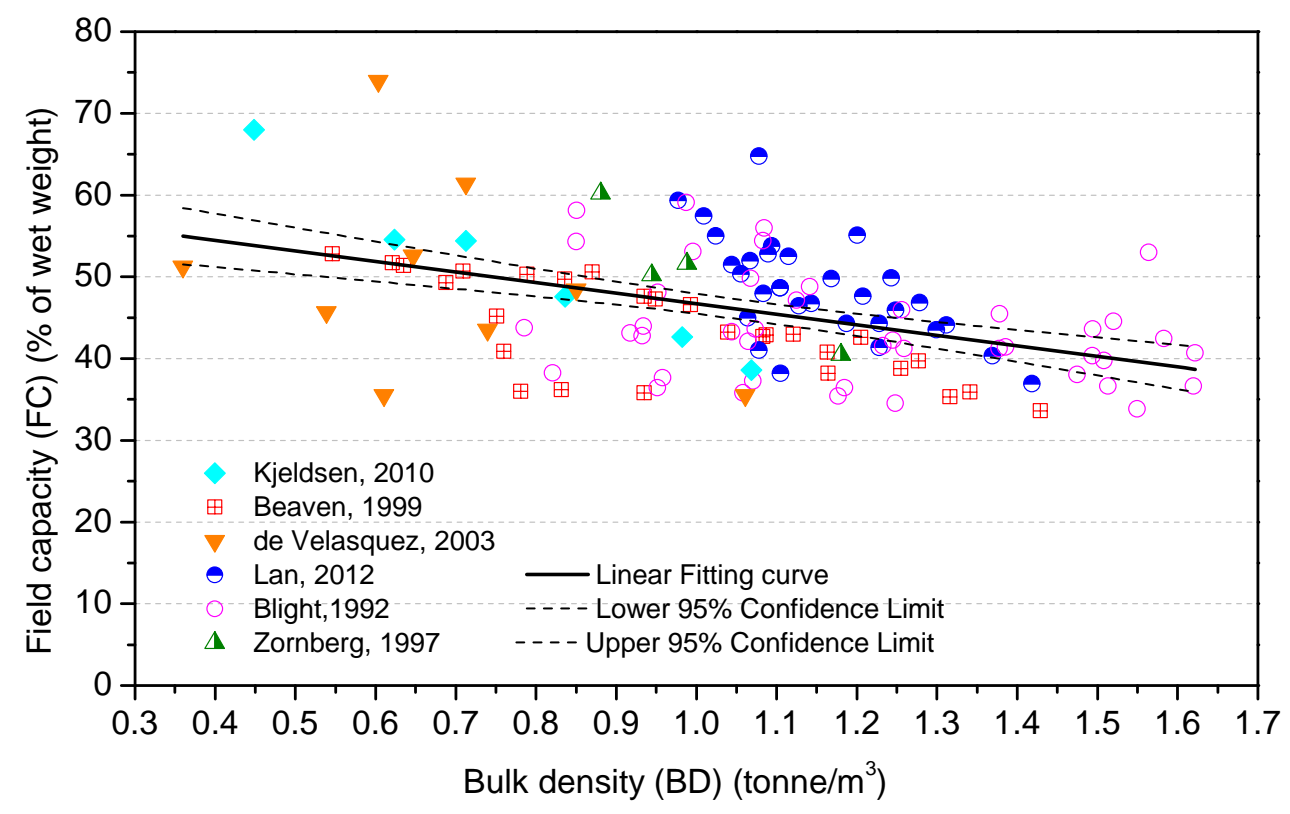

Figure S3 Linear fitting of field capacity and bulk density for municipal solid waste.

The fitting equation is $\mathrm{FC}=(59.6 \pm 2.5)-(12.9 \pm 2.3) \times \mathrm{BD}$.

\section{References in SI}

Beaven, R., 1999. The hydrogeological and geotechnical properties of househould waste in relation to sustainable landfilling, Department of Civil Engineering. The University of London, London, UK.

Blakey, N., 1982. Absorptive capacity of refuse-WRC Research., in: Research, H. (Ed.), Proceedings of a Landfill Leachate Symposium. Harwell Research, Harwell, UK.

Blight, G.E., Ball, J.M., Blight, J.J., 1992. Moisture and suction in sanitary landfills in semiarid areas. Journal of Environmental Engineering 118, 865-877.

Campbell, D., 1982. Absorptive capacity of refuse-WRC Research., in: Research, H. (Ed.), Proceedings of a Landfill Leachate Symposium. Harwell Research, Harwell, UK.

Cao, J.Y., 2007. A study on leachate mifration in MSW landfill under biodegradation effect (in Chinese), Municipal Engineering. Southwest Jiaotong University, Chengdu, p. 40.

de Velasquez, M.T.O., Cruz-Rivera, R., Rojas-Valencia, N., Monje-Ramirez, I., Sanchez-Gomez, J., 2003. Determination of field capacity of municipal solid waste with surcharge simulation. Waste Manage. Res. 21, 137-144.

Fungarioli, A.A., Steiner, R., 1979. Investigation of sanitary landfill behaviour volume 1, Final report. EPA-600-2-79-053a. USEPA, Washington, D.C., USA.

Gao, Q.X., Du, W.P., Lu, S.Q., Zhang, Z.G., Zhang, E.S., Wu, J.G., Ren, Z.H., 2007. The Measurement and Research of Degradable Organic Carbon of Municipal Solid Waste in China. Research of Environmental Sciences (in Chinese) 20, 10-15. 
He, J.B., Yao, Q.J., Han, Z.M., An, J.J., Liu, K.Q., Tang, Y., Peng, W.G., 2010. Investigation and analysis of domestic waste within the south area of Haihe river in Tianjin Binhai new area. Environmental Sanitation Engineering (in Chinese) 18, 7-10.

He, S., Zhu, S., Yu, L., 2008. Characteristics analysis and treatment countermeasures of domestic waste in Suzhou city. Environmental Sanitation Engineering (in Chinese) 16.

Holmes, R., 1980. The water balance method of estimating leachate production from landfill sites, Solid Waste, 1.

Huang, B.S., Li, X.H., Wang, L.A., Cui, Z.Q., 2003. Analysis of Physicochemical Preoperty and Discussion of Disposal of MSW in the Urban Zone of Chongqing City. Journal of Chongqingi University (in Chinese) 26, 9-13.

Huang, M.X., Liu, D., 2012. Characteristics and compositions of municipal solid waste in Sichuan Province Environmental Monitoring in China (in Chinese) 28, 121-123.

Ji, A.M., 2007. The analysis of physical characteristics and incinerating feasibility of municipal solid waste in Lanzhou (in Chinese), Environmental Engineering. Lanzhou University, Lanzhou.

Jiang, J.G., Lou, Z.Y., Ng, S., Luobu, C., Ji, D., 2009. The current municipal solid waste management situation in Tibet. Waste Manage. 29, 1186-1191.

Jiang, Z., Zhang, W., Qi, W., 2011. Physical Properties and Change Regularity of Domestic Waste in Qingdao City. Environmental Sanitation Engineering (In Chinese) $19,36-41$.

Jin, J., 2006. Research on property of household waste in Hefei and bio-waste treated by earthworm (in Chinese). Hefei University of Technology, Hefei, China.

Kinman, R.N., Richabaugh, J.I., Walsch, J.J., Vogt, W.G., 1982. Leachate from co-disposal of municipal and hazardous waste in landfill simulators, in: EPA (Ed.), Proceedings of the EPA eighth annual research symposium: Land disposal of hazardous wastes. EPA-600/9-82-002, Kentucky, USA, pp. 274-293.

Kjeldsen, P., Beaven, R., 2011. Landfillling: Hydrology. Blackwell Publishing Ltd., West Sussex, United Kingdom.

Lan, J.W., 2012. Mechanism of leachate generation, transport and mound in MSW landfills and control of leachate level (in Chinese), Constructional Engineering. Zhejiang University, Hangzhou, China.

Li, L., 2010. Sustainable Development Research on the Urban and Rural Domestic Refuse Disposal in Wuhan. Ecological Economy (in Chinese) 5, 156-158.

Ma, Z.Z., 2010. Domestic wasteinvestigation and disposal method in Shenyang city. Environmental Sanitation Engineering (in Chinese) 18, 13-18.

Ministry of Construction of the People's Republic of China, 2006. High density polyethylene geomembrane for landfills (CJ/T234-2006) (in Chinese), Chinese industrial standard. China Architecture \& Building Press, Beijing, China.

Ministry of Housing and Urban-Rural Development of the people's republic of China, 2012. Technical code for geotechnical engineering of municipal solid waste sanitary landfill (CJJ176-2012) (in Chinese), Chinese industrial standard. China Architecture \& Building Press, Beijing, China. 
Qu, X., He, P., Shao, L., Li, G., 2005. Research on hydraulic conductivity test of compacted municipal solid waste. Techniques and Equipment for Environmental Pollution Control (in Chinese) 6, 13-17.

Robinson, H.D., Barber, C., Maris, P.J., 1981. Generation and treatment of leachate from domestic waste in landfills. Water Pollution Control 81, 465-478.

Rovers, F.A., Farquhar, G.J., 1973. Infiltration and landfill behaviours. ASCE Journal of Environmental Engineering 99, 671-690.

Schroeder, P.R., Lloyd, C., Zappi, P., Aziz, N., 1994. The hydrologic evaluation of landfill performance (HELP) model. Engineering Dcumentation for Version 3, NTIS PB 95-212700. US EPA Office of Research and Development, Washington D.C.

Shao, H.W., Xu, W.L., Kong, J.J., Patiguli, Ge, C.H., Zhang, Y.S., Yu, J., Wei, W., 2009. Investigation and estimation of domestic waste in Urumqi. Environmental Sanitation Engineering (in Chinese) 17, 10-12.

Shenzhen Environmental Sanitary Management Department, 2011. Statistical analysis of municipal solid waste characteristics in Shenzhen (in Chinese).

Wang, H., Wang, C.M., 2013. Municipal solid waste management in Beijing: characteristics and challenges. Waste Manage. Res. 31, 67-72.

Xie, B., 2009. Study on the waste degradation behavior and stabilization of dumping sites in northeaste China (in Chinese), Environmental Science and Engineering. Harbin Institute of Technology, Harbin.

Zhang, Y., Yang, X.H., WANG, X.Y., 2009. Survey Report of MSW Characteristics in Shanghai (in Chinese). Shanghai Institute for Design \& Research on Environmental Engineering, Shanghai.

Zhuang, Y., Wu, S.W., Wang, Y.L., Wu, W.X., Chen, Y.X., 2008. Source separation of household waste, a case study in China. Waste Manage. 28.

Zornberg, J.G., Jernigan, B.L., Sanglerat, T.R., H., C.B., 1999. Retention of free liquids in landfills undergoing vertical expansion. Journal of Geotechnical and Geoenvironmental Engineering 125, 583-594. 